\title{
Dissolution of Different Reservoir Rocks by Organic Acids in Laboratory Simulations: Implications for the Effect of Alteration on Deep Reservoirs
}

\author{
Jian Chen $\mathbb{D}^{1,2}$ Jie Xu, ${ }^{1,2,3}$ Susu Wang, ${ }^{1,2,3}$ Zhenyu Sun, ${ }^{1,2,3}$ Zhong Li, ${ }^{3,4}$ Wanglu Jia $\mathbb{D}^{1,2}$ \\ and Ping'an Peng ${ }^{1,2,3}$ \\ ${ }^{1}$ State Key Laboratory of Organic Geochemistry (SKLOG), Guangzhou Institute of Geochemistry, Chinese Academy of Sciences, \\ Guangzhou 510640, China \\ ${ }^{2}$ CAS Center for Excellence in Deep Earth Science, Guangzhou 510640, China \\ ${ }^{3}$ University of Chinese Academy of Sciences, Beijing 100049, China \\ ${ }^{4}$ State Key Laboratory of Lithospheric Evolution, Institute of Geology and Geophysics, Chinese Academy of Sciences, \\ Beijing 100029, China
}

Correspondence should be addressed to Jian Chen; chenjian@gig.ac.cn

Received 22 October 2020; Revised 7 February 2021; Accepted 2 March 2021; Published 23 March 2021

Academic Editor: Mercè Corbella

Copyright (c) 2021 Jian Chen et al. This is an open access article distributed under the Creative Commons Attribution License, which permits unrestricted use, distribution, and reproduction in any medium, provided the original work is properly cited.

\begin{abstract}
Organic acids are important agents in the alteration of deep reservoirs. It is difficult, however, to assess the impact of organic acid alteration on deep reservoirs because different dissolution processes may occur during diagenesis. This study simulated the dissolution of three different types of reservoir rocks by acetic acid in a closed system and compared the mineral and elemental composition, surface morphology, pore structure, and water chemistry variations of the initial and altered samples. The study demonstrated that both micrite and sucrosic dolostone are strongly dissolved, losing about $20 \%-30 \%$ of their initial rock sample weights. Observation under SEM showed that the limestone dissolved homogenously, whereas the dolostone showed honeycomb-like dissolution. Both carbonate samples showed the development of large voids, including holes and cavities of micrometer scale, but nanopores of various sizes were blocked. In contrast, lithic arkose was heterogeneously altered, losing a weight proportion of about $13 \%$ by dissolution of calcite cement. These micrometer-scale microfissures were developed, but those nanometer-scale pores just varied in a narrow range of sizes. The volume increase in all three reservoir types is mainly attributed to the dissolution of carbonate minerals. In deep reservoirs, in situ generated organic acids can enlarge existing cavities in carbonates and develop microfissures in sandstones. The microfissure porosity in sandstone is limited but can increase through other geological processes such as overpressure. More importantly, these acids can maintain the acidity of pore waters, inhibit the precipitation of dissolved minerals, and help to preserve reservoir porosity. Although temperature plays an insignificant role in laboratory simulations, it influences both the generation and destruction processes of organic acids in deep reservoirs on geologic time scales and, thus, warrants further attention. The results provide a basis for recognizing the typical patterns of organic acid dissolution on different reservoir rocks and further suggest the potential role of organic acids in the formation and preservation of secondary porosity in deeply buried reservoirs.
\end{abstract}

\section{Introduction}

Organic acids have been widely detected in waters associated with hydrocarbons in petroleum-bearing basins worldwide [1-3]. Consisting mainly of acetic acid, they donate $\mathrm{H}^{+}$ions to fluids and thus influence mineral stability [4-6]. However, their roles in reservoir alteration are uncertain. Secondary porosity generation by acid dissolution is suggested by laboratory simulations, theoretical calculations, and field observations (e.g., etched texture in bleached red sandstones) [5, 7-10]. It has also been argued that organic acids play a negligible role in reservoir diagenesis, considering the minor 

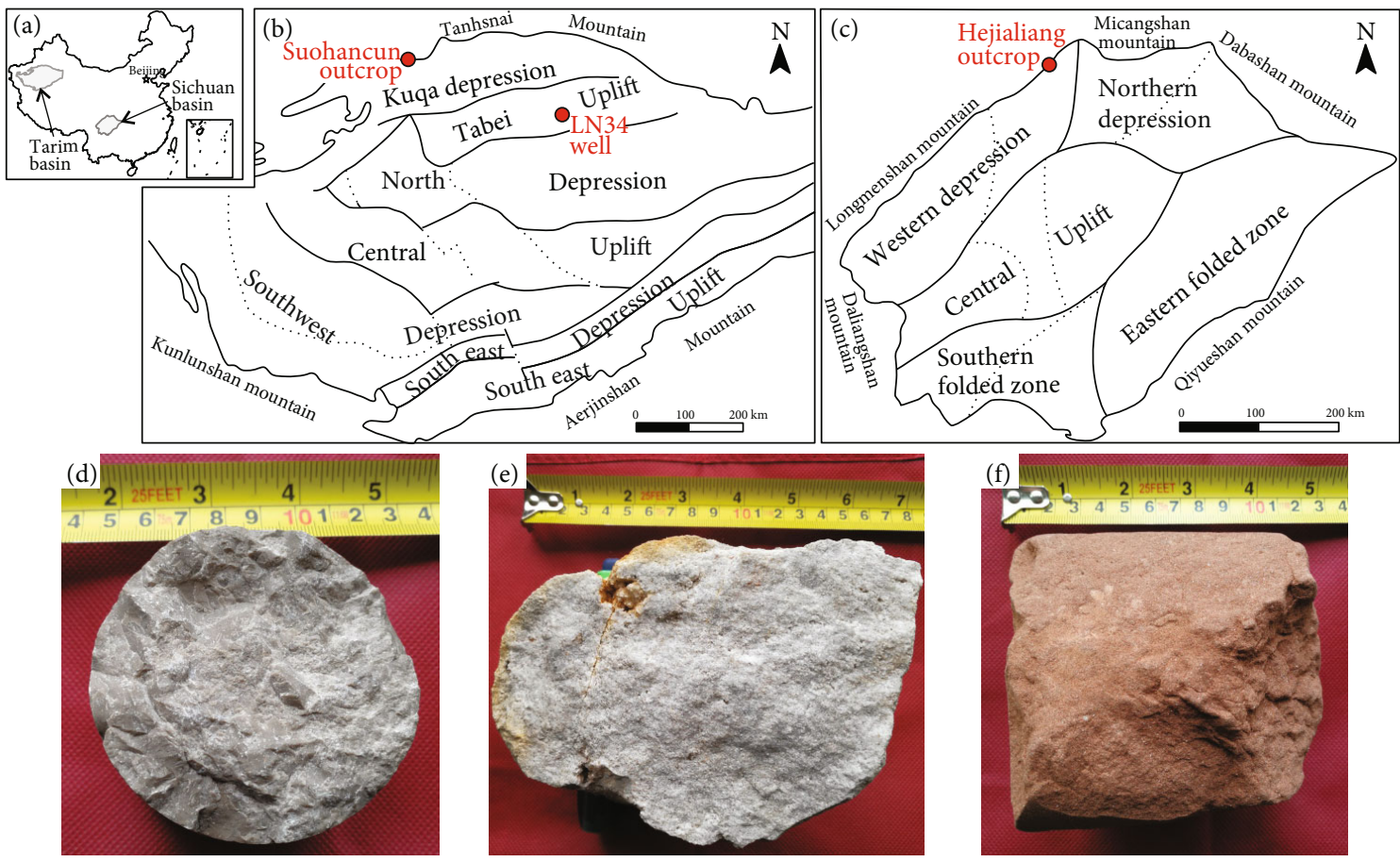

Figure 1: Location and images of the rock samples: (a) map of China showing the location of the Tarim and Sichuan basins; (b) structural map of Tarim Basin showing the location of well LN34 and Suohancun outcrop; (c) structural map of Sichuan Basin showing the location of Hejialiang outcrop; $(\mathrm{d})$ hand specimen of micrite from the Ordovician Yingshan formation $\left(\mathrm{O}_{1 \mathrm{y}}\right)$ in well LN34 (5156-5165 m below sea level); (e) hand specimen of sucrosic dolostone from the Permian Qixia formation $\left(\mathrm{P}_{1 \mathrm{q}}\right)$ in the Hejialiang outcrop; and (f) hand specimen of lithic arkose the Cretaceous Bashijiqike formation $\left(\mathrm{K}_{1 \mathrm{bs}}\right)$ in the Suohancun outcrop.

TABLE 1: Mineralogical compositions of initial and altered rock samples.

\begin{tabular}{|c|c|c|c|c|c|c|c|c|c|c|c|}
\hline Simulation & $\begin{array}{c}\text { Temperature } \\
\left({ }^{\circ} \mathrm{C}\right)\end{array}$ & $\begin{array}{c}\text { Quartz } \\
(\%)\end{array}$ & $\begin{array}{c}\text { Calcite } \\
(\%)\end{array}$ & $\begin{array}{c}\text { Dolomite } \\
(\%)\end{array}$ & $\begin{array}{c}\text { Albite } \\
(\%)\end{array}$ & $\begin{array}{c}\text { Microcline } \\
(\%)\end{array}$ & $\begin{array}{c}\text { Chlorite } \\
(\%)\end{array}$ & $\begin{array}{c}\text { Illite } \\
(\%)\end{array}$ & $\begin{array}{c}\text { Kaolinite } \\
(\%)\end{array}$ & $\begin{array}{c}\text { Montmorillonite } \\
(\%)\end{array}$ & $\begin{array}{c}\text { Hematite } \\
(\%)\end{array}$ \\
\hline \multirow{6}{*}{$\begin{array}{l}\text { Limestone } \\
\text { series }\end{array}$} & Initial $^{\mathrm{a}}$ & 0.2 & 96.9 & 2.9 & $-{ }^{b}$ & - & - & - & - & - & - \\
\hline & 50 & 0.3 & 95.4 & 4.3 & - & - & - & - & - & - & - \\
\hline & 75 & 0.4 & 94.9 & 4.7 & - & - & - & - & - & - & - \\
\hline & 100 & 0.2 & 97.1 & 2.7 & - & - & - & - & - & - & - \\
\hline & 150 & 0.2 & 98.2 & 1.5 & - & - & - & - & - & - & - \\
\hline & 200 & 0.2 & 97.7 & 2.1 & - & - & - & - & - & - & - \\
\hline \multirow{6}{*}{$\begin{array}{l}\text { Dolostone } \\
\text { series }\end{array}$} & Initial & 0.1 & 1.1 & 98.8 & - & - & - & - & - & - & - \\
\hline & 50 & - & 0.2 & 99.8 & - & - & - & - & - & - & - \\
\hline & 75 & - & 0.2 & 99.8 & - & - & - & - & - & - & - \\
\hline & 100 & - & 0.2 & 99.8 & - & - & - & - & - & - & - \\
\hline & 150 & - & 0.1 & 99.9 & - & - & - & - & - & - & - \\
\hline & 200 & - & 0.2 & 99.8 & - & - & - & - & - & - & - \\
\hline \multirow{6}{*}{$\begin{array}{l}\text { Sandstone } \\
\text { series }\end{array}$} & Initial & 42.4 & 11.7 & - & 11.6 & 3.7 & 17.0 & 11.3 & 0.7 & 0.5 & 0.1 \\
\hline & 50 & 49.1 & - & - & 15.1 & 4.4 & 16.9 & 12.4 & 0.5 & 1.3 & 0.3 \\
\hline & 75 & 44.7 & - & - & 10.6 & 6.6 & 22.3 & 12.8 & 0.8 & 2.1 & 0.2 \\
\hline & 100 & 48.0 & - & - & 13.4 & 3.8 & 18.1 & 12.6 & 0.9 & 3.0 & 0.1 \\
\hline & 150 & 41.8 & - & - & 13.8 & 7.4 & 18.7 & 13.5 & 0.6 & 4.0 & 0.1 \\
\hline & 200 & 49.9 & - & - & 11.0 & 5.1 & 19.4 & 11.3 & 0.3 & 2.8 & 0.1 \\
\hline
\end{tabular}

${ }^{\mathrm{a}}$ Initial sample; ${ }^{\mathrm{b}}$ Not detected. 


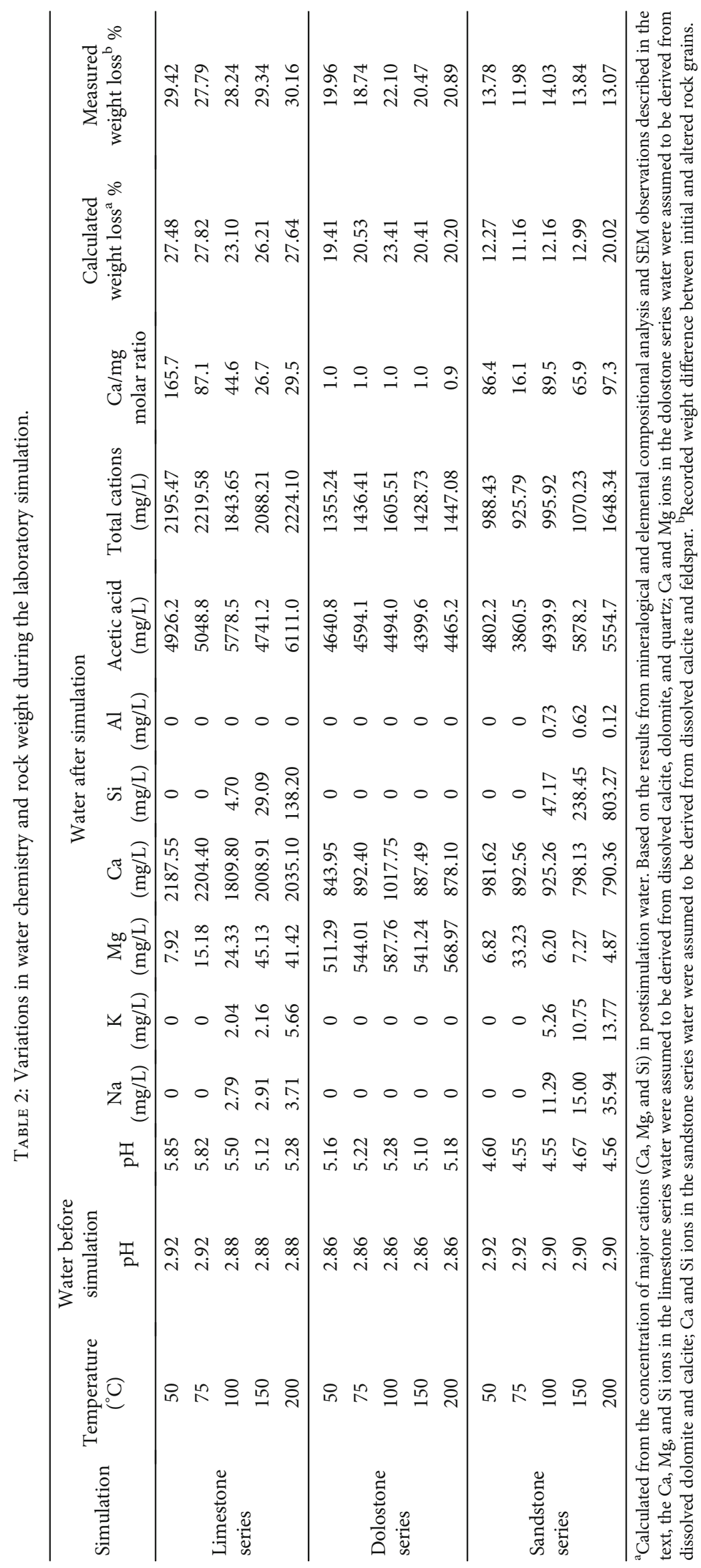




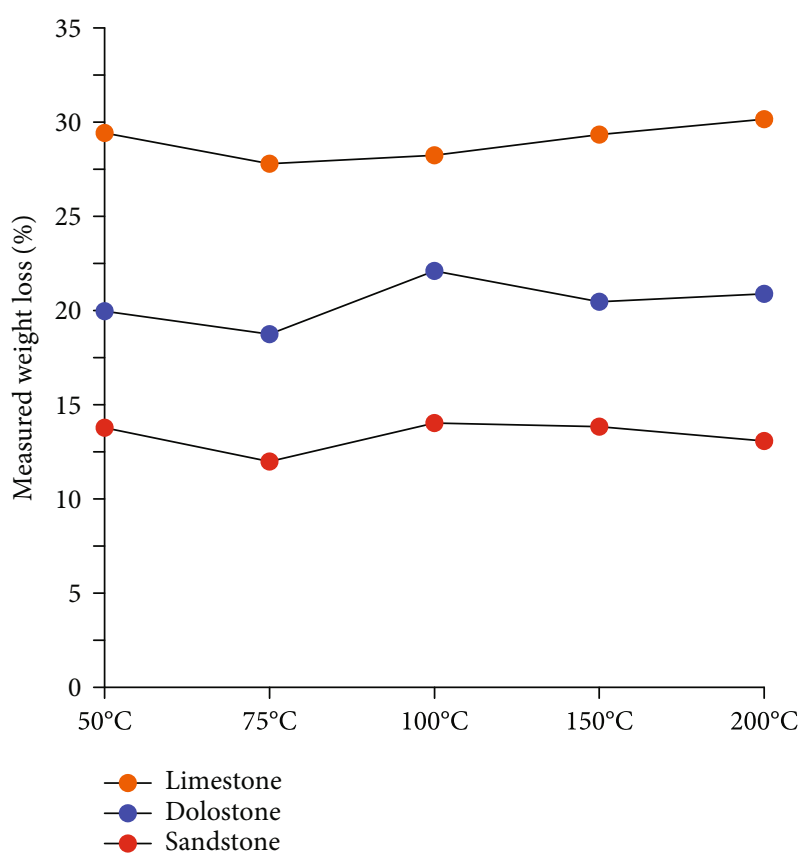

Figure 2: Measured weight loss of rock grains during the simulation, measured by the weight difference of rock grains before and after the simulation.

amount of organic acid generated from source rocks, neutralization of the acids by minerals before fluids migrate into reservoirs, and precipitation of dissolved minerals by decarboxylation [11-13]. Nevertheless, recent petroleum exploration in the basins of western China has revealed that hydrocarbons, including light oils and gas, have accumulated in specific reservoir intervals, mainly karstified limestone, corroded dolostone, and microfissured sandstone at depths $>5 \mathrm{~km}$ [14-16]. The secondary alteration of primary porosity is believed to play an important role in the preservation and development of these deep reservoirs. Alteration of reservoirs related to the influx of acidic fluids from source rocks has been proposed $[15,16]$; however, there is insufficient evidence to support this view.

Previous studies have sought to simulate the alteration of reservoir rocks by organic acids. Most of this research has involved experiments on pure minerals to calculate dissolution rates and dissolution kinetics and identify the dissolution mechanisms [17-19]. Based on these results, additional research was carried out using minerals or rocks under a range of simulation conditions (e.g., varying $\mathrm{pH}$, salinity, and acid type) to investigate the environmental factors controlling the interaction between organic acids and minerals [20-22]. However, there has been little research comparing the different responses of reservoir rocks to dissolution by organic acids. Reservoir rocks composed of different minerals should show specific corrosion patterns and porosity variations under acid dissolution. These specific characteristics could help to estimate the development of reservoir porosity.

This study simulated the dissolution by acetic acid of different types of reservoir rocks in a closed system under a range of temperatures. These rocks included micrite, sucrosic dolostone, and lithic arkose. All are important hydrocarbonbearing reservoirs in the basins of western China [14-16]. Mineral and elemental composition, pore distribution, corrosion patterns, and water chemistry were compared for initial and altered samples. The overall aims of this study are to (1) identify specific corrosion patterns and typical dissolution effects of organic acids on different reservoir rocks and (2) discuss the role of organic acids in reservoir alteration, especially for deeply buried reservoirs.

\section{Samples and Experiments}

2.1. Samples. The laboratory simulation considered three rock types: micrite from the Ordovician Yingshan formation $\left(\mathrm{O}_{1 \mathrm{y}}\right)$ in the LN34 well (at 5156-5165 m below sea level), Tarim Basin; medium-coarsely crystalline dolostone (sucrosic dolostone) from the Permian Qixia formation $\left(\mathrm{P}_{1 \mathrm{q}}\right)$ in the Hejialiang outcrop, northwest Sichuan Basin; and the Cretaceous Bashijiqike lithic arkose $\left(\mathrm{K}_{1 \mathrm{bs}}\right)$ in the Suohancun outcrop of the Kuqa Depression, Tarim Basin (Figures 1(a)-1(c)).

The Yingshan limestone consists mainly of grainstone, micrite, and biolithite [23]. The micrite is gray to brown (Figure $1(\mathrm{~d})$ ), and is composed, based on microscopic observation, of $>90 \%$ calcite mud with $<10 \%$ calcite grains [24]. The micrite was deposited in an intershoal sea or intraplatform depression $[23,24]$. The micrite used in the simulation consists of calcite (96.9\%) plus minor dolomite (2.9\%) and quartz $(0.2 \%$, Table 1$)$. The sucrosic dolostone from the first member of the Qixia formation is composed of anhedral to subhedral, medium-coarse grains (Figure 1(e)). It was deposited as an open-sea platform [25]. Grain development in the sucrosic dolostone is attributed to evaporative seawater seepage reflux and penecontemporaneous seawater cyclic hydrothermal fluid dolomitization [26]. The dolostone used in the simulation consists of dolomite (98.8\%), minor calcite (1.0\%), and quartz $(0.1 \%$; Table 1$)$. The lithic arkose from the second member of the Bashijiqike Formation was deposited as a braided fan or delta front facies under semiarid to arid climatic conditions [16]. It is mineralogically immature, texturally moderate to mature, has moderate sorting, and has a high content of feldspar and rock fragments that are subangular to subrounded (Figure 1(f)) $[16,27]$. Analysis by X-ray diffraction (XRD) shows that the lithic arkose used in the simulation consists of quartz (42.4\%), clay (29.5\%), feldspar (15.3\%), calcite $(11.7 \%)$, and hematite $(0.1 \%$, Table 1$)$. Carbonate minerals are mainly present as cements, based on previous research [27]. In the rest of the paper, micrite, sucrosic dolostone, and lithic arkose are simply referred to as limestone, dolostone, and sandstone, respectively.

The rock samples were crushed, and grains for the simulation were selected from the size range of 60 to 120 mesh $(0.250$ to $0.125 \mathrm{~mm})$ - which is the standard for lowpressure $\mathrm{CO}_{2}$ and $\mathrm{N}_{2}$ adsorption experiments. Grains were used because they react rapidly with acetic acid and show clear textures after dissolution.

2.2. Laboratory Simulations in a Closed System. To observe the dissolution features in a simulation performed over a 
TABLE 3: Major element contents of initial and altered rock samples.

\begin{tabular}{lccccccccccccc}
\hline Simulation & $\begin{array}{c}\mathrm{Temperature} \\
\left({ }^{\circ} \mathrm{C}\right)\end{array}$ & $\begin{array}{c}\mathrm{Na}_{2} \mathrm{O} \\
\%\end{array}$ & $\begin{array}{c}\mathrm{MgO} \\
\%\end{array}$ & $\begin{array}{c}\mathrm{Al}_{2} \mathrm{O}_{3} \\
\%\end{array}$ & $\begin{array}{c}\mathrm{P}_{2} \mathrm{O}_{5} \\
\%\end{array}$ & $\begin{array}{c}\mathrm{K}_{2} \mathrm{O} \\
\%\end{array}$ & $\begin{array}{c}\mathrm{CaO} \\
\%\end{array}$ & $\begin{array}{c}\mathrm{TiO}_{2} \\
\%\end{array}$ & $\begin{array}{c}\mathrm{MnO}_{\%} \\
\%\end{array}$ & $\begin{array}{c}\mathrm{Fe}_{2} \mathrm{O}_{3} \mathrm{~T}^{\mathrm{a}} \\
\%\end{array}$ & $\begin{array}{c}\mathrm{LOI}^{\mathrm{b}} \\
\%\end{array}$ & $\begin{array}{c}\mathrm{SiO}_{2} \\
\%\end{array}$ & $\begin{array}{c}\mathrm{Total}^{2} \\
\%\end{array}$ \\
\hline Limestone & $\mathrm{Initial}^{\mathrm{c}}$ & 0.01 & 0.89 & 0.15 & 0.01 & 0.04 & 54.43 & 0.01 & 0.00 & 0.06 & 42.89 & 1.32 & 99.82 \\
series & 50 & 0.02 & 1.12 & 0.16 & 0.01 & 0.04 & 54.50 & 0.01 & 0.00 & 0.08 & 42.66 & 1.20 & 99.81 \\
& 75 & 0.03 & 1.10 & 0.15 & 0.01 & 0.05 & 54.45 & 0.01 & 0.00 & 0.15 & 42.71 & 1.11 & 99.77 \\
& 100 & 0.01 & 0.89 & 0.15 & 0.01 & 0.04 & 55.10 & 0.01 & 0.00 & 0.07 & 42.40 & 1.06 & 99.73 \\
& 150 & 0.01 & 0.65 & 0.16 & 0.01 & 0.04 & 55.55 & 0.01 & 0.00 & 0.07 & 42.23 & 1.01 & 99.74 \\
& 200 & 0.01 & 0.70 & 0.12 & 0.01 & 0.02 & 55.73 & 0.02 & 0.00 & 0.06 & 42.21 & 0.92 & 99.81 \\
\hline \multirow{4}{*}{ Dolostone } & Initial & 0.06 & 21.94 & 0.05 & 0.02 & 0.01 & 31.43 & 0.00 & 0.01 & 0.15 & 45.62 & 0.53 & 99.83 \\
series & 50 & 0.02 & 21.94 & 0.07 & 0.01 & 0.01 & 31.55 & 0.00 & 0.00 & 0.13 & 45.64 & 0.44 & 99.81 \\
& 75 & 0.02 & 22.05 & 0.08 & 0.01 & 0.02 & 31.24 & 0.00 & 0.00 & 0.13 & 45.83 & 0.48 & 99.87 \\
& 100 & 0.02 & 21.98 & 0.07 & 0.01 & 0.02 & 31.50 & 0.00 & 0.00 & 0.12 & 45.68 & 0.36 & 99.77 \\
& 150 & 0.02 & 21.98 & 0.08 & 0.01 & 0.01 & 31.63 & 0.00 & 0.00 & 0.12 & 45.61 & 0.38 & 99.85 \\
& 200 & 0.02 & 21.93 & 0.07 & 0.01 & 0.01 & 31.87 & 0.00 & 0.00 & 0.13 & 45.54 & 0.33 & 99.91 \\
\hline Sandstone & Initial & 1.50 & 1.60 & 8.72 & 0.09 & 1.61 & 6.83 & 0.40 & 0.07 & 3.04 & 7.28 & 68.65 & 99.78 \\
series & 50 & 1.62 & 1.78 & 9.42 & 0.09 & 1.83 & 0.30 & 0.42 & 0.03 & 3.13 & 2.66 & 78.55 & 99.83 \\
& 75 & 1.60 & 1.76 & 9.23 & 0.09 & 1.84 & 0.29 & 0.43 & 0.03 & 3.39 & 2.32 & 78.87 & 99.85 \\
& 100 & 1.69 & 1.83 & 10.01 & 0.09 & 1.90 & 0.32 & 0.46 & 0.03 & 3.24 & 2.73 & 77.58 & 99.88 \\
& 150 & 1.49 & 1.78 & 9.83 & 0.09 & 1.79 & 0.36 & 0.46 & 0.04 & 3.31 & 3.09 & 77.57 & 99.80 \\
& 200 & 1.59 & 1.79 & 9.77 & 0.09 & 1.84 & 0.36 & 0.46 & 0.04 & 3.37 & 3.05 & 77.46 & 99.80 \\
\hline
\end{tabular}

${ }^{\mathrm{a}} \mathrm{Fe}_{2} \mathrm{O}_{3} \mathrm{~T}$ : total iron as $\mathrm{Fe}_{2} \mathrm{O}_{3}$; ${ }^{\mathrm{b}} \mathrm{LOI}$ : weight loss on ignition; ${ }^{\mathrm{c}}$ Initial sample.

set time, a solution with $0.1 \mathrm{~mol} / \mathrm{L}$ of acetic acid was used. Samples of rock grains $(0.5 \mathrm{~g})$ and acetic acid $(25 \mathrm{~mL})$ were loaded in $35 \mathrm{~mL}$ titanium alloy vessels. The vessels were then ventilated by argon for at least $1 \mathrm{~min}$ to displace the air and then sealed. A series of laboratory simulations was undertaken with these vessels at $50^{\circ} \mathrm{C}, 75^{\circ} \mathrm{C}, 100^{\circ} \mathrm{C}, 150^{\circ} \mathrm{C}$, and $200^{\circ} \mathrm{C}$, each for 72 hours. To collect sufficient rock grains for further analysis, 12 vessels were used in simulations involving limestone (the limestone series), and 10 vessels were used in simulations involving dolostone and sandstone (the dolostone and sandstone series).

2.3. Instrumental Analysis. The difference between the weight of the rock grains before and after simulation was recorded as the measured weight loss. The rock grains were observed using a scanning electron microscope (SEM) and analyzed by $\mathrm{N}_{2}$ and $\mathrm{CO}_{2}$ adsorption methods before and after simulation, then crushed into powders ( $<200$ mesh). The powders were analyzed for mineral and major elemental compositions by X-ray diffraction (XRD) and inductively coupled plasmaoptical emission spectrometry (ICP-OES). In this study, SEM was used for observation of large pores $(>1 \mu \mathrm{m})$ in rock grains, and low-pressure $\mathrm{CO}_{2}$ and $\mathrm{N}_{2}$ adsorption provided distribution information about nanopores $(<1 \mu \mathrm{m})$ in three classes: macropores $(50-300 \mathrm{~nm})$, mesopores $(2-50 \mathrm{~nm})$, and micropores $(<2 \mathrm{~nm})$.

Rock grain surfaces were observed using the SEM (Hitachi SU8010 system) equipped with secondary electron and backscattered electron detectors both before and after simulation. Working distances during field emission SEM observations ranged from 4 to $8 \mathrm{~mm}$ at $1.5 \mathrm{kV}$. Energy-dispersive
$\mathrm{X}$-ray spectroscopy was used to determine the elemental composition of rock grains.

A surface area and porosity analyzer (Micromeritics ASAP 2460) was used to carry out low-pressure $\mathrm{CO}_{2}$ and $\mathrm{N}_{2}$ adsorption experiments to describe the structure and distribution of nanopores. Prior to analysis, rock grains were dried at $60^{\circ} \mathrm{C}$ for $24 \mathrm{~h}$ and then degassed at $80^{\circ} \mathrm{C}$ for a further $24 \mathrm{~h}$. The $\mathrm{CO}_{2}$ adsorption was performed at $273 \mathrm{~K}$ with a relative pressure $\mathrm{P} / \mathrm{Po}$ ranging from 0.00003 to 0.03 , and the volumes and pore-size distributions of micropores were determined by the density functional theory (DFT) model. The $\mathrm{N}_{2}$ adsorption was carried out at $77 \mathrm{~K}$ with a relative pressure varying from 0.005 to 0.995 , and the volumes and pore-size distributions of mesopores and macropores were derived by the Barrett-Joyner-Halenda (BJH) model. More details about the procedure may be found in previous research [28].

The mineral contents of the rock powders were measured by XRD using a Rigaku D/max 2500 instrument with a $\mathrm{Cu}$ $\mathrm{K} \alpha$ radiation source. The $\mathrm{XRD}$ was operated at $40 \mathrm{kV}$ and $250 \mathrm{~mA}$ and scanned from $3^{\circ}$ to $70^{\circ}$ at a rate of $5^{\circ} / \mathrm{min}$. The major elements in the grains were determined by ICP-OES (Agilent 720). Different preparation procedures using $\mathrm{HF} / \mathrm{HNO}_{3}$ and $\mathrm{NaOH}$ solutions for acid digestion were used to determine major elements (except $\mathrm{SiO}_{2}$ ) and $\mathrm{SiO}_{2}$, respectively. About $1 \mathrm{mg}$ of the samples was weighed in crucibles and heated at $900^{\circ} \mathrm{C}$ in a muffle furnace for ca. $1 \mathrm{~h}$. The weight difference between before and after ignition was recorded as the loss-on-ignition (LOI). Analytical accuracy was estimated to be $\pm 2 \%$ (relative). The concentration of cations in solution was also analyzed by ICP-OES (Varian Vista-Pro), with an analytical uncertainty better than $5 \%$. 

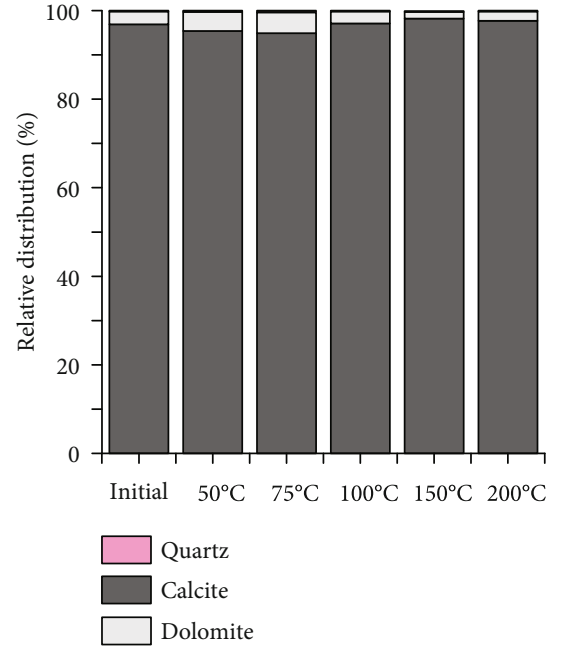

(a)

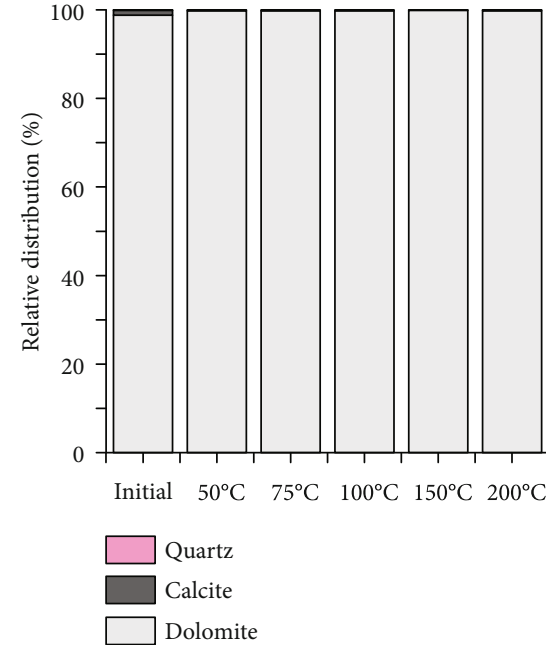

(b)

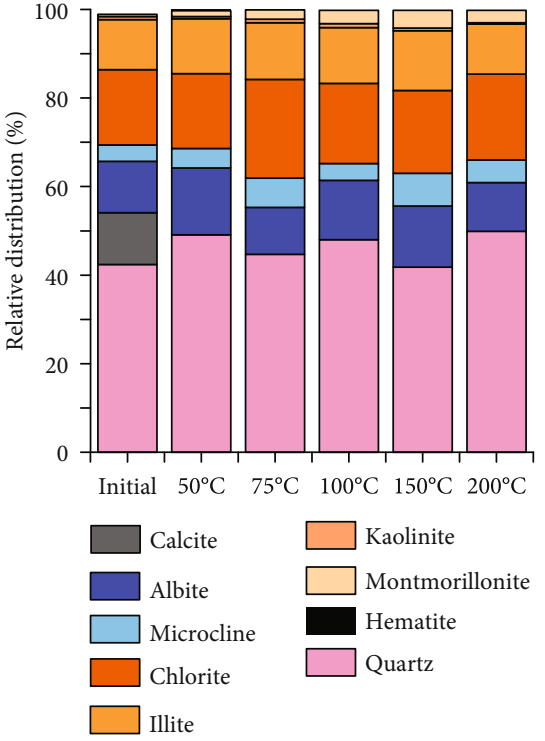

(c)

FIgure 3: Mineralogical composition of initial and altered rock grains: (a) limestone series; (b) dolostone series; and (c) sandstone series. "Initial" describes initial rock grains. All data were normalized to $100 \%$.

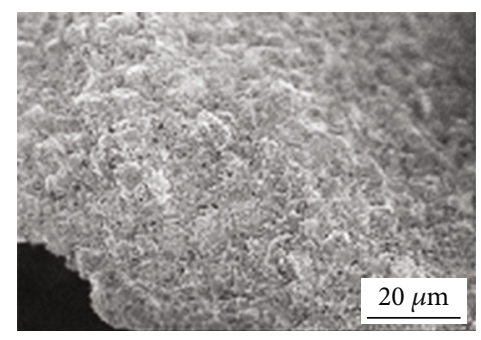

(a)

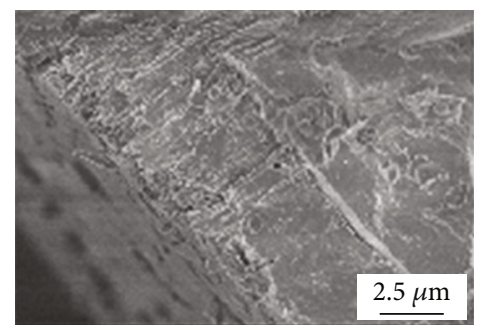

(d)

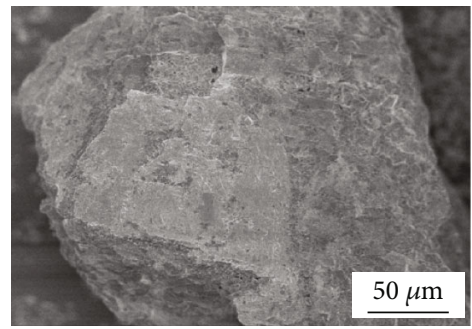

(g)

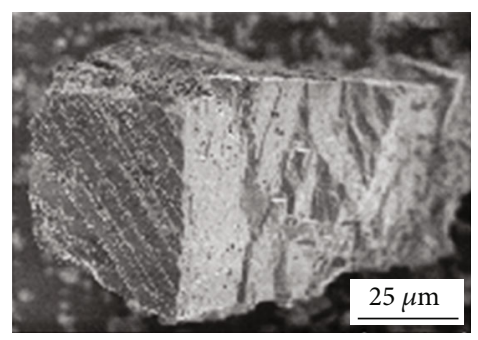

(b)

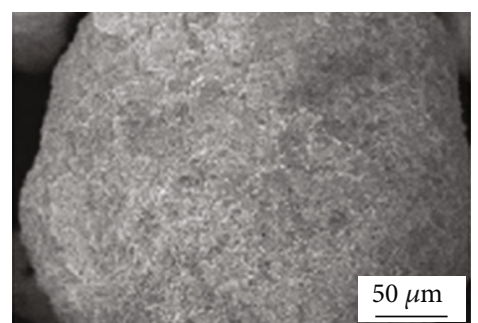

(e)

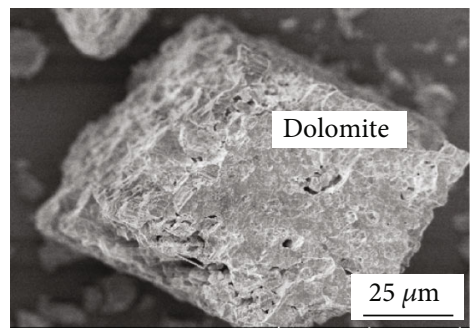

(h)

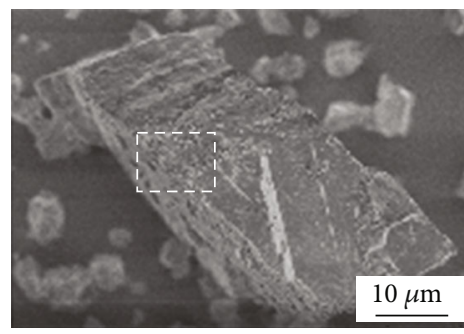

(c)

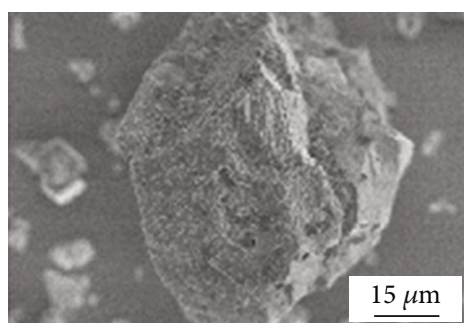

(f)

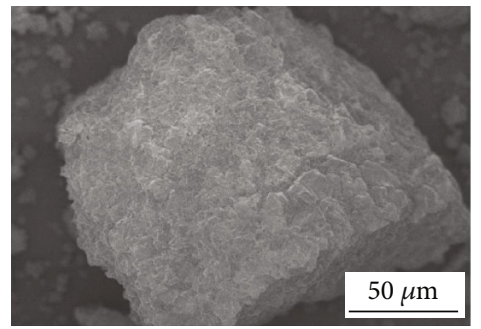

(i)

FIgURE 4: SEM images of initial and altered rock grains in the limestone series. (a) Calcite grain with few pores in initial limestone; (b) crystalline calcite without pores in initial limestone; (c) crystalline calcite with a corroded edge at $50^{\circ} \mathrm{C}$; (d) enlarged image of corroded edge (dotted box in $4 \mathrm{c})$; (e-g) calcite with blurred grain boundaries at $100^{\circ} \mathrm{C}(\mathrm{e})$ and $150^{\circ} \mathrm{C}(\mathrm{f}-\mathrm{g})$; (f) corroded dolomite crystal at $150^{\circ} \mathrm{C}$; (i) calcite with blurred grain boundary at $200^{\circ} \mathrm{C}$. 


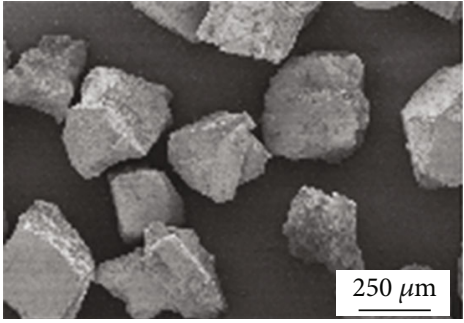

(a)

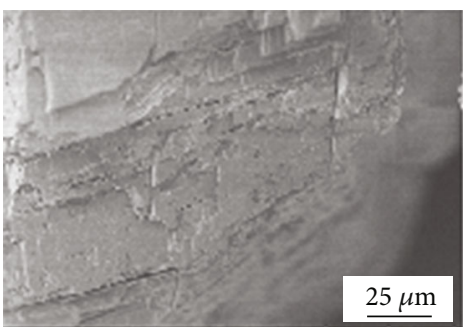

(d)

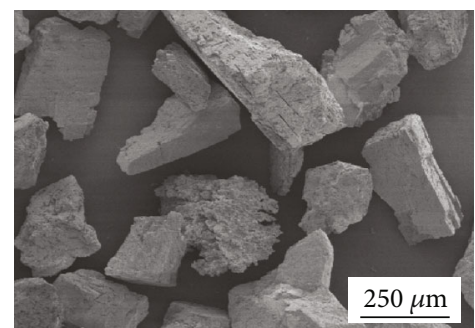

(g)

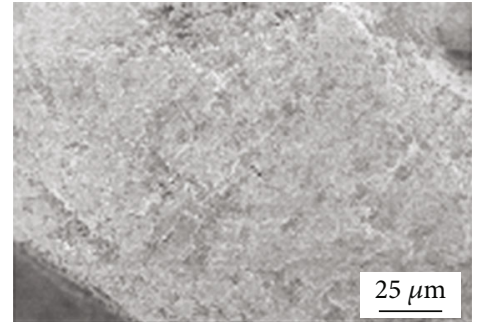

(b)

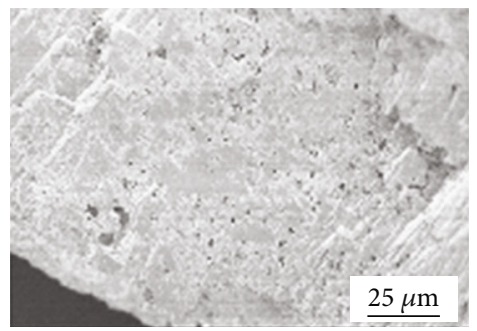

(e)

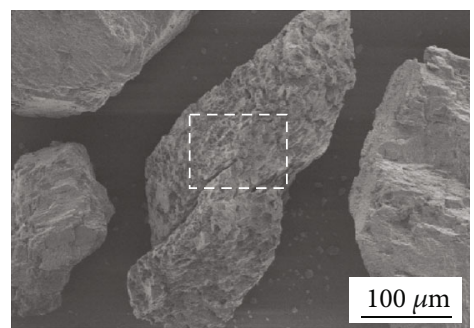

(h)

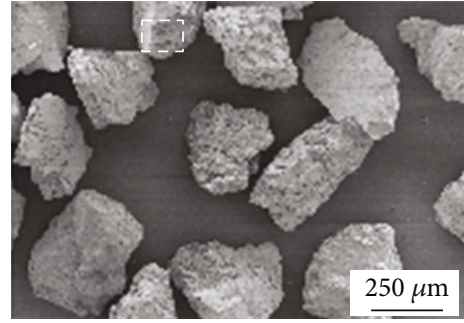

(c)

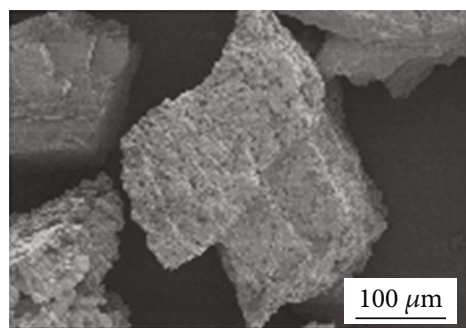

(f)

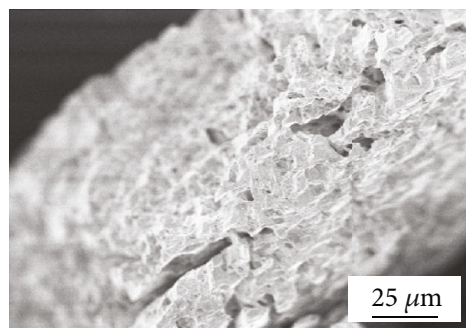

(i)

FIGURE 5: SEM images of initial and altered rock grains in the dolostone series. (a) Grains with smooth, flat surfaces in initial dolostone; (b) smooth surface of an uncorroded grain with no pore development in initial dolostone; (c) corroded grains at $50^{\circ} \mathrm{C}$; (d) enlarged image of dotted box in $5 \mathrm{c}$ showing etched fissures along the cleavage; (e) etched pits at $75^{\circ} \mathrm{C}$; (f-h) etched grains with honeycomb-like pores at 100 , 150 , and $200^{\circ} \mathrm{C}$, respectively; (i) enlarged image of dotted box in $5 \mathrm{~h}$ showing honeycomb-like pores at $200^{\circ} \mathrm{C}$.

The $\mathrm{pH}$ values of water before and after simulations were determined using a pH meter (PHS-3E; Inesa Incorporation). The concentration of acetic acids in simulation water after 200 times dilution was measured by ionic chromatography, using a Dionex ICS900 instrument, with an AS15 ion exchange column and $\mathrm{KOH}$ eluent. The $\mathrm{KOH}$ flow rate was maintained at $1.0 \mathrm{~mL} \mathrm{~min}^{-1}$ following a gradient elution program from 5 to $55 \mathrm{mmol} / \mathrm{L}$. Sextuple analyses of the same sample yielded a precision of better than $6 \%$.

\section{Results}

3.1. Water Chemistry and Rock Weight. The $\mathrm{pH}$ value of the $0.1 \mathrm{~mol} / \mathrm{L}$ acetic acid solution ranged initially from 2.86 to 2.92 (Table 2). After simulation, the acids were neutralized completely by cations released from the dissolved minerals, and the final $\mathrm{pH}$ values increased to a range between 4.55 and 5.85. The postsimulation water in the limestone series exhibited the highest $\mathrm{pH}$ values (5.12-5.85), whereas the sandstone series had the lowest (4.55-4.67). The $\mathrm{pH}$ of the postsimulation water in the dolostone series was intermediate (5.10-5.28). No clear $\mathrm{pH}$ variation with elevated temperatures was observed in the simulations.
The concentration of acetic acid in the postsimulation water ranged from 3860.5 to $6111.0 \mathrm{mg} / \mathrm{L}$. The decrease in acid content was attributed to the accelerated decarboxylation process, which was catalyzed by the rock grain minerals and impurities on the surface of the vessel used in the experiments $[29,30]$. The composition and concentration of cations in the postsimulation water varied to a large degree among the series (Table 2). In the limestone series, the Ca concentration showed little variation during the simulation, ranging from 1809.80 to $2204.40 \mathrm{mg} / \mathrm{L}$. Four cations, Na, K, $\mathrm{Mg}$, and $\mathrm{Si}$, increased with temperature, although at low concentrations. The $\mathrm{Ca} / \mathrm{Mg}$ molar ratio was 165.7 at $50^{\circ} \mathrm{C}$, then decreased gradually to 29.5 with increasing temperature. In the dolostone series, the $\mathrm{Ca}$ and $\mathrm{Mg}$ concentrations ranged from 843.95 to $1017.75 \mathrm{mg} / \mathrm{L}$ and 511.29 to $587.76 \mathrm{mg} / \mathrm{L}$, respectively; however, the $\mathrm{Ca} / \mathrm{Mg}$ molar ratio remained at 1.0 during all stages of the simulation. In the sandstone series, the $\mathrm{Ca}$ and $\mathrm{Mg}$ concentrations ranged from 892.56 to $981.62 \mathrm{mg} / \mathrm{L}$ and 6.82 to $33.23 \mathrm{mg} / \mathrm{L}$, respectively, at low temperatures (at $50^{\circ} \mathrm{C}$ and $75^{\circ} \mathrm{C}$ ). In the subsequent hightemperature stages $\left(100^{\circ} \mathrm{C}\right.$ to $\left.200^{\circ} \mathrm{C}\right)$, more cations were detected, including $\mathrm{Na}, \mathrm{K}, \mathrm{Si}$, and $\mathrm{Al}$. The concentrations of $\mathrm{Na}, \mathrm{K}$, and $\mathrm{Si}$ increased in line with temperature, whereas 


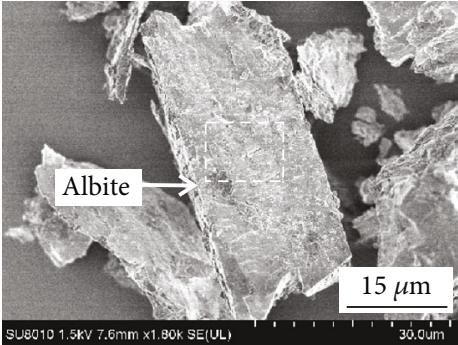

(a)

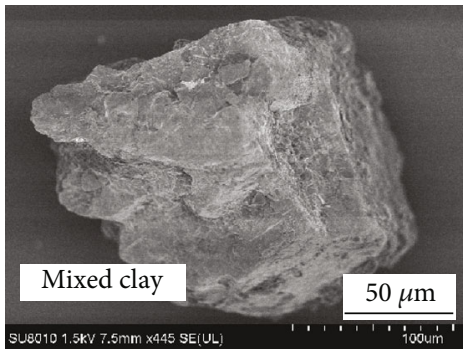

(d)

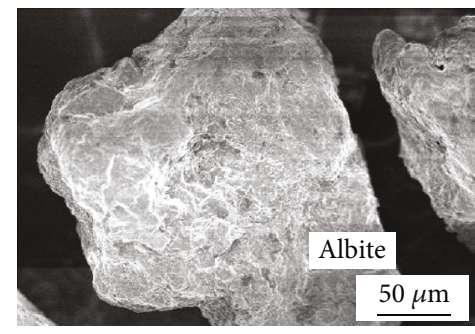

(g)

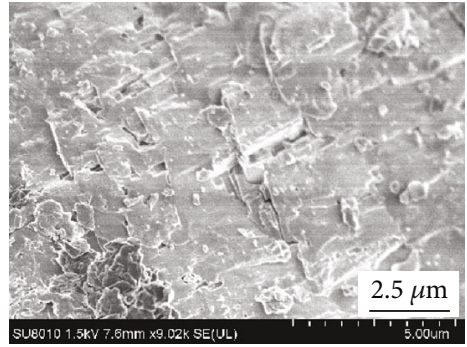

(b)

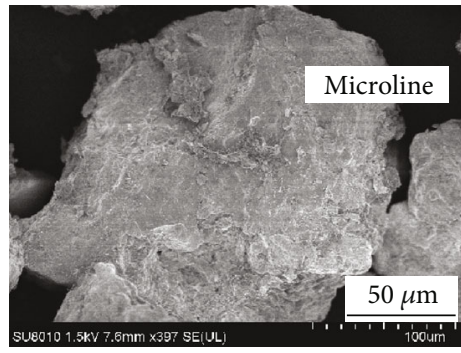

(e)

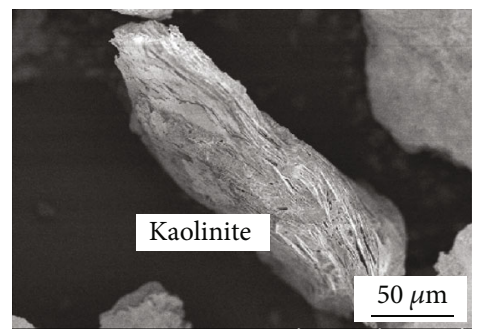

(h)

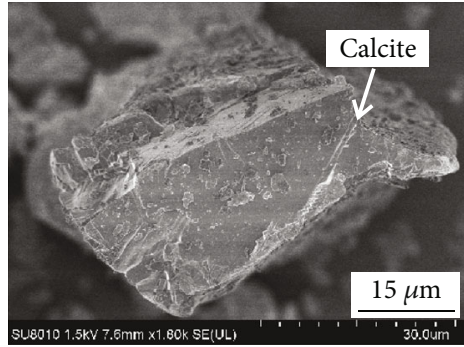

(c)

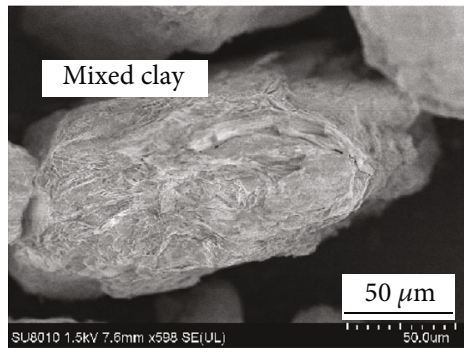

(f)

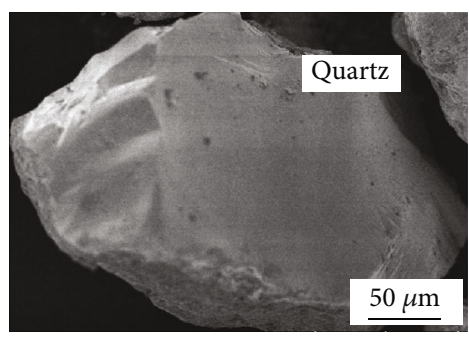

(i)

FIGURE 6: SEM images of initial and altered rock grains in the sandstone series. (a) Albite crystal in initial sandstone; (b) enlarged image of dotted box in 6(a) showing no pore development on the albite surface; (c) calcite crystal in initial sandstone; (d) mixed clay at $50^{\circ} \mathrm{C}$; (e) microcline grain at $75^{\circ} \mathrm{C}$; (f) mixed clay at $100^{\circ} \mathrm{C}$; (g) albite at $150^{\circ} \mathrm{C}$; (h) kaolinite with interlayer pores at $150^{\circ} \mathrm{C}$; (i) quartz grain with smooth surface at $200^{\circ} \mathrm{C}$. All minerals marked in this figure were determined by energy-dispersive X-ray spectroscopy.

those of $\mathrm{Ca}, \mathrm{Mg}$, and $\mathrm{Al}$ decreased slightly. At $200^{\circ} \mathrm{C}$, Si concentration $(803.27 \mathrm{mg} / \mathrm{L})$ was the most dominant in postsimulation water, exceeding that of $\mathrm{Ca}(790.36 \mathrm{mg} / \mathrm{L})$. The $\mathrm{Ca} / \mathrm{Mg}$ molar ratio decreased from 86.4 to 16.1 at $50^{\circ} \mathrm{C}-$ $75^{\circ} \mathrm{C}$, then increased to 97.3 at $200^{\circ} \mathrm{C}$.

The measured weight loss of rock grains decreased from the limestone $(27.79 \%-30.16 \%)$ to dolostone $(18.74 \%-$ $20.89 \%)$ and to sandstone $(11.98 \%-14.03 \%)$ series (Figure 2). This loss is consistent with the weight loss calculated from concentrations of major cations in postsimulation water, which showed the limestone, dolostone, and sandstone grains were dissolved by $23.10 \%-27.82 \%, 19.41 \%-$ $23.41 \%$, and $11.16 \%-20.02 \%$, respectively (Table 2 ). The postsimulation water of sandstone at $200^{\circ} \mathrm{C}$ with a high $\mathrm{Si}$ content yielded a large calculated weight loss $(20.02 \%)$. As was observed with the $\mathrm{pH}$ value, weight loss was independent of the simulation temperature.

3.2. Mineral and Elemental Composition. The mineral and elemental compositions of grains were measured by XRD and ICP-OES, respectively. Upon comparison of the two methods, ICP-OES seems to be more sensitive to the detection of compositional changes during dissolution (Tables 1 and 3).
The initial limestone consisted mainly of calcite (96.9\%; Table 1). The relative proportion of dolomite and quartz increased slightly in the low-temperature stages $\left(50^{\circ} \mathrm{C}-\right.$ $\left.75^{\circ} \mathrm{C}\right)$, then decreased at higher temperatures $\left(100^{\circ} \mathrm{C}-\right.$ $200^{\circ} \mathrm{C}$, Figure $3(\mathrm{a})$ ) during the dissolution simulation. The compositional trend exhibited by dolomite and quartz was also shown in the elemental variation of $\mathrm{MgO}$ and $\mathrm{SiO}_{2}$ (Table 3). The initial dolostone consisted primarily of dolomite $(98.8 \%)$, with minor calcite $(1.1 \%)$ and quartz $(0.1 \%)$. During the simulation, most of the calcite and all of the quartz were dissolved (Figure 3(b)), although an extremely low $\mathrm{SiO}_{2}$ content $(0.33-0.48 \%)$ was detected during ICPOES analysis of the altered dolostone. The initial sandstone consisted of quartz (42.4\%), clay (29.5\%, including chlorite, illite, kaolinite, and montmorillonite), feldspar (15.3\%, including albite and microcline), calcite (11.7\%), and hematite $(0.1 \%)$. The acetic acid dissolved all calcite but did not appear to change the relative proportion of other minerals in the simulation (Figure 3(c)). According to the elemental composition data, the $\mathrm{CaO}$ content decreased significantly from $6.83 \%$ in the initial sandstones to $0.29 \%-0.36 \%$ in the altered sandstones. The variation in mineral and elemental compositions of the dolostone and sandstone series was not 

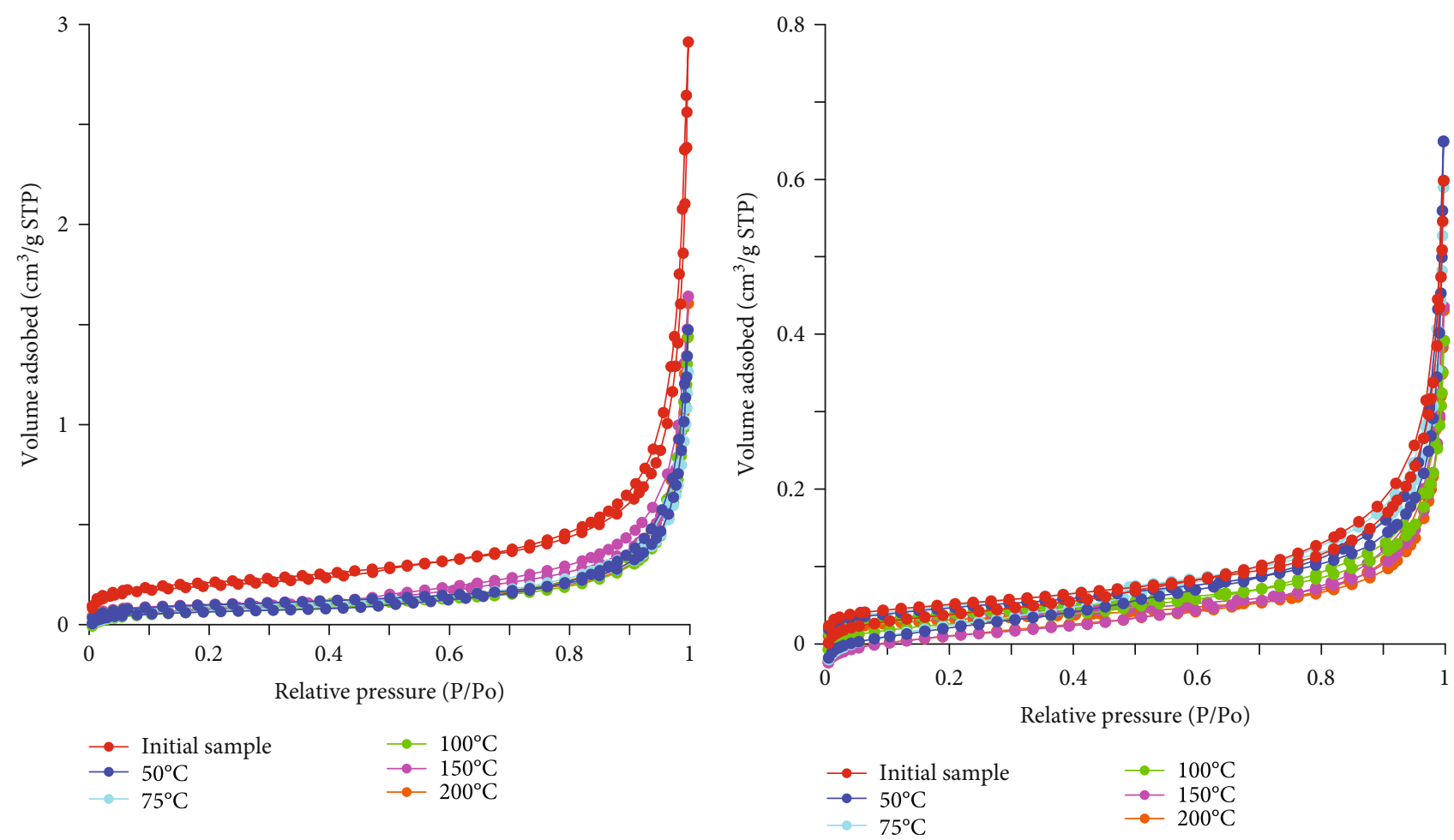

(a)
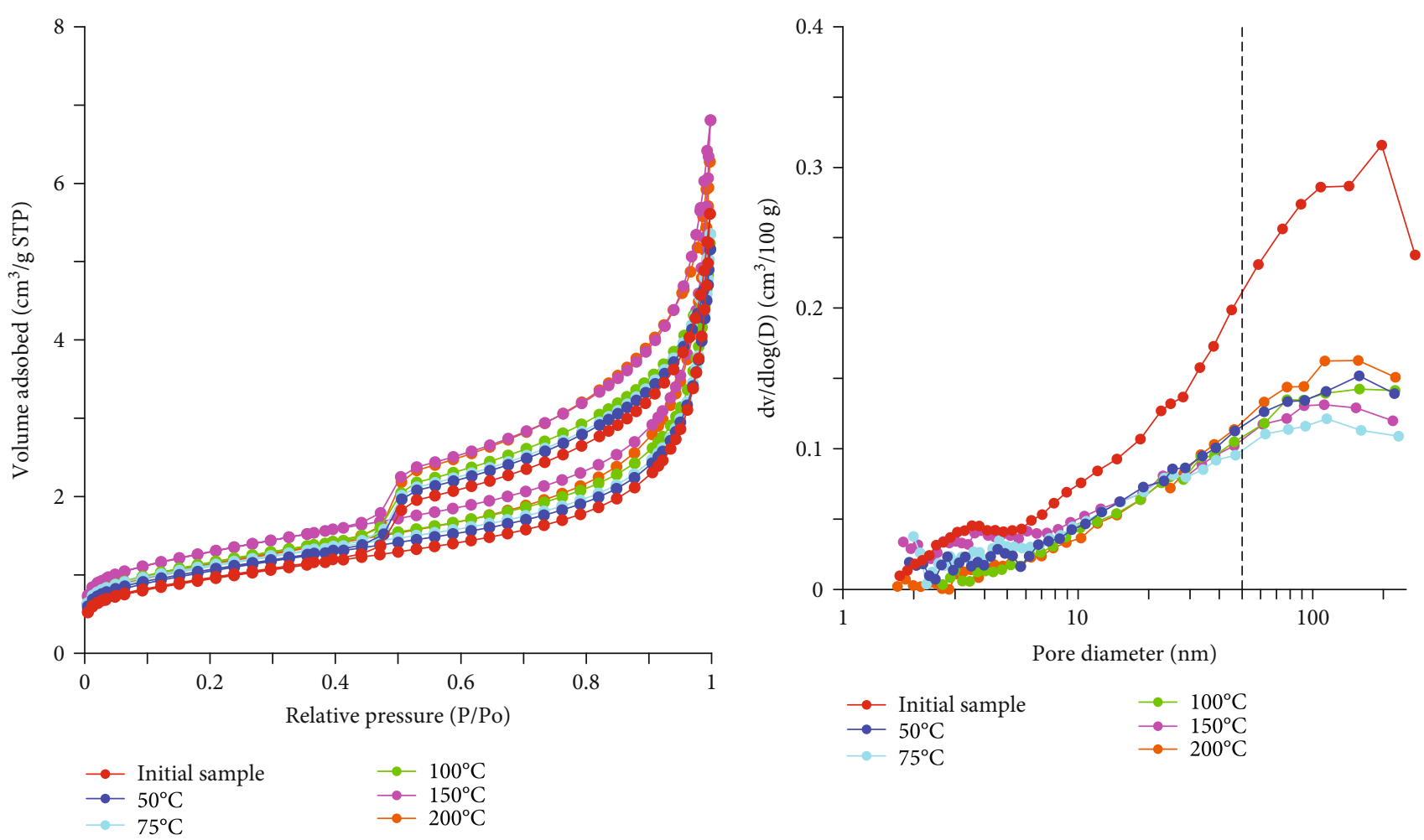

(c)

(d)

Figure 7: Continued. 


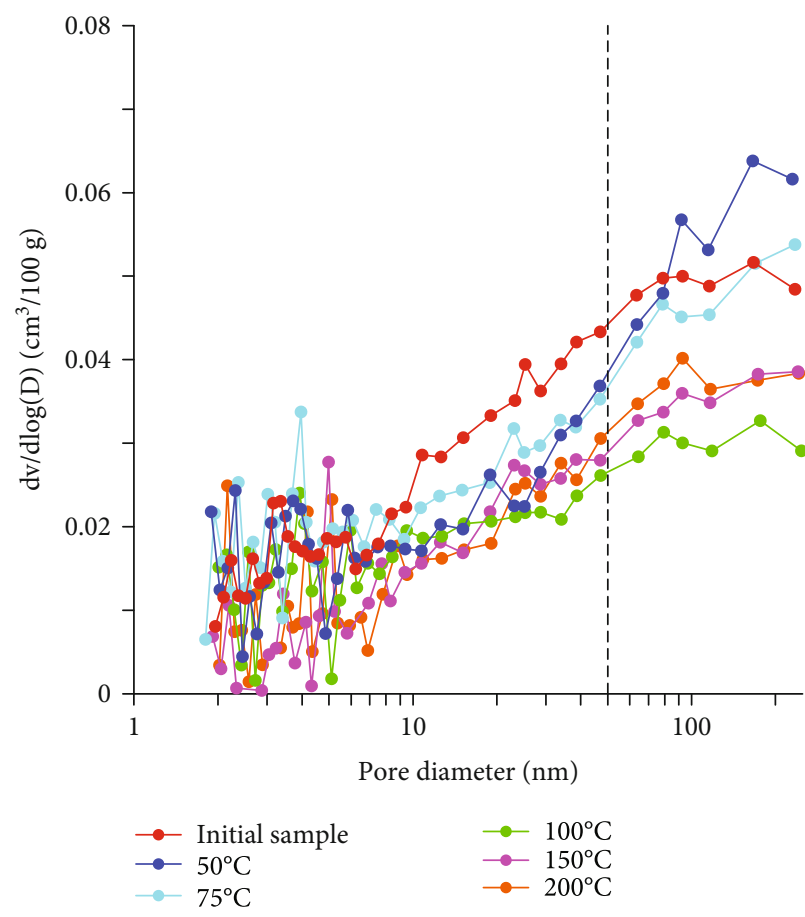

(e)

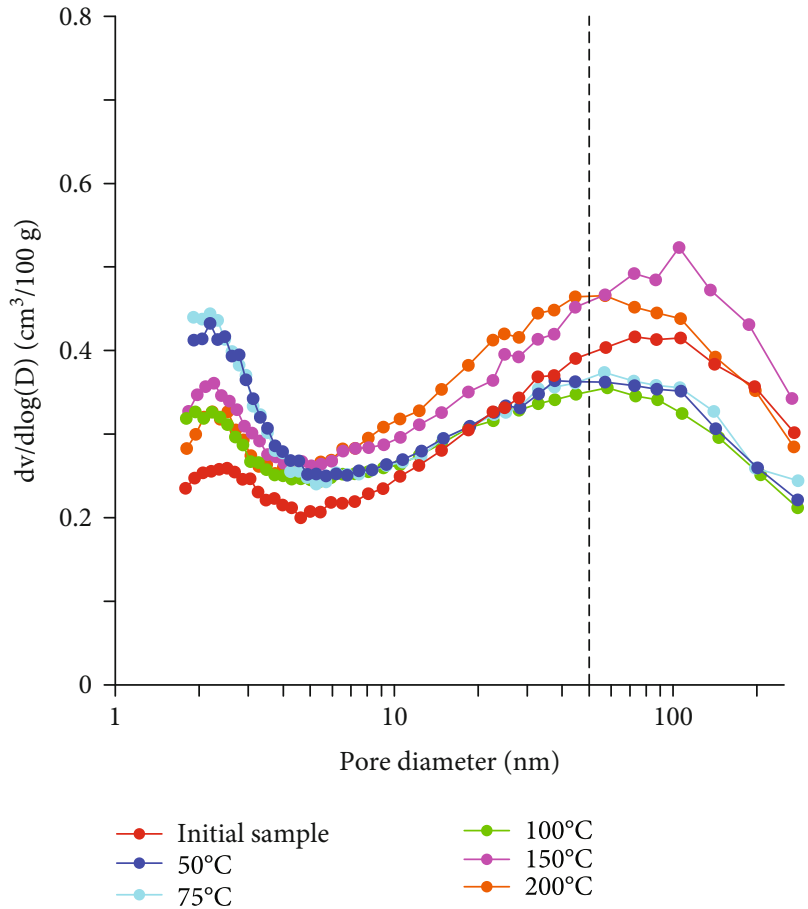

(f)

FiguRE 7: $\mathrm{N}_{2}$ adsorption isotherms for initial and altered rock grains ((a) limestone series, (b) dolostone series, and (c) sandstone series) and pore volume distribution with pore size derived from $\mathrm{N}_{2}$ adsorption isotherms using the BJH model ((d) limestone series, (e) dolostone series, and (f) sandstone series). Dotted lines in $7(\mathrm{~d})$ and $7(\mathrm{f})$ differentiate macropores $(>50 \mathrm{~nm})$ and mesopores $(2-50 \mathrm{~nm})$. Note that numerical scales differ among the $y$-axes.

related to simulation temperature, in contrast to the limestone series which varied compositionally with simulation temperature.

3.3. SEM Observations. Most of the initial limestone exhibited stacks of fine-grained micrite $(<4 \mu \mathrm{m}$, Figure $4(\mathrm{a}))$, whereas a few samples had well-shaped crystals (Figure 4(b)). Few large pores were observed in these limestones. After the simulation, the limestone grains were severely dissolved and showed varying degrees of corrosion. The edges of some grains were partly etched (Figures 4(c) and $4(\mathrm{~d})$ ), although most grains were homogeneously dissolved and grain boundaries were blurred (Figures 4(e)4(g) and 4(i)). The dolomite, which represented only a minor component, was only partly dissolved and thus kept its crystal form (Figure 4(h)). No clear morphological difference was observed between altered limestones under different temperatures, and the large pore distribution was not noticeably altered by acid dissolution.

In the initial dolostone samples, the grains were smooth and flat, and large pores were poorly developed (Figures 5(a) and 5(b)). Most of these grains were dissolved considerably during the simulations (Figures 5(c) and 5(f)5(h)). However, three different dissolution textures can be observed in enlarged SEM images: etched fissures, pits, and honeycomb-like pores (Figures 5(d)-5(e) and 5(i)). These textures were observed in different grains of altered dolostones at all temperatures. Large pores were highly developed in the altered dolostones, compared with the initial samples, but there was no observed difference in the pore distribution in dolostones that were altered during different temperature stages.

Few large pores were observed in most of the minerals in the initial sandstone during SEM analysis, including feldspar, calcite, and quartz, whereas clay minerals exhibited porous interlayers (Figures 6(a)-6(c)). In the simulation, calcite was dissolved completely by acetic acid, which also etched the surface of feldspars and the interlayers of clay minerals (Figures 6(d)-6(h)). The morphology of quartz in all sandstone samples was unaffected by the simulation (Figure 6(i)). Large pores were enlarged to a degree by acetic acid dissolution, but variations in large pore distribution among altered sandstone samples at different simulation temperatures were not observed.

3.4. $\mathrm{N}_{2}$ and $\mathrm{CO}_{2}$ Adsorption. The $\mathrm{N}_{2}$ adsorption-desorption cycles of the initial limestone series are Type II isotherms (Figure 7(a)), which have been interpreted as a response to unrestricted monolayer-multilayer adsorption [31]. The initial limestone samples showed poor adsorption capacity with a maximum volume of $<3 \mathrm{~cm}^{3} / 100 \mathrm{~g}$. After the simulation, the adsorption capacity of the rock grains was visibly decreased, compared with that of the initial samples. The pore-volume distribution within pore sizes of $1.7-300 \mathrm{~nm}$ showed the pore structure of the initial sample was unimodal with a peak at $160 \mathrm{~nm}$ (Figure $7(\mathrm{~d})$ ). The simulation did not change the pore distribution, but strongly decreased the volume of mesopores and macropores (Figure 8(a); Table 4). In 


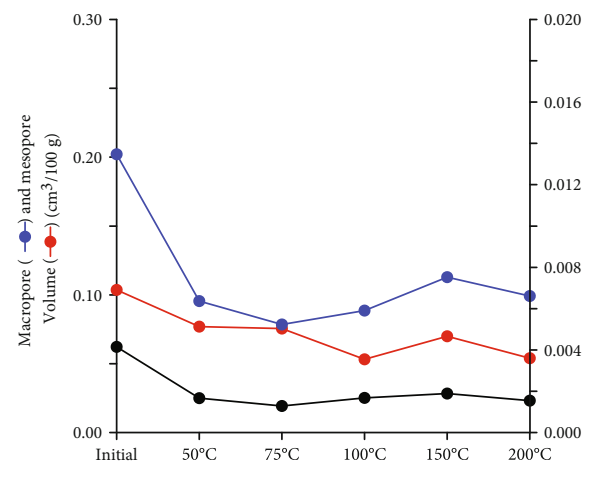

(a) Limestone

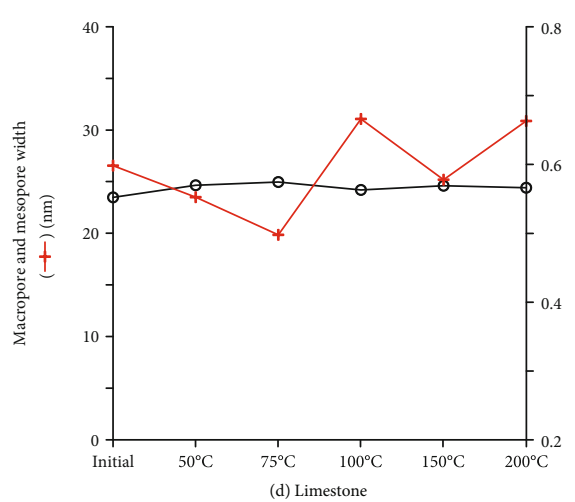

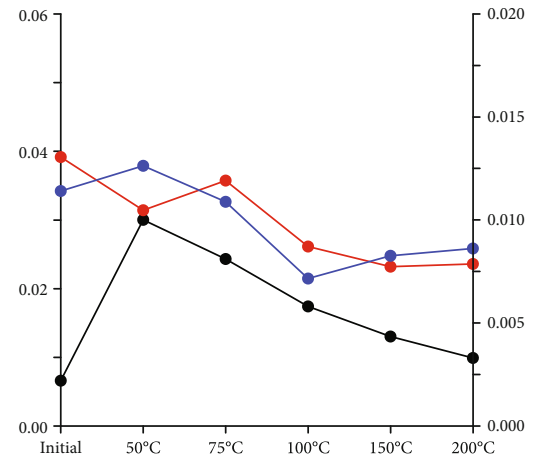

(b) Dolostone

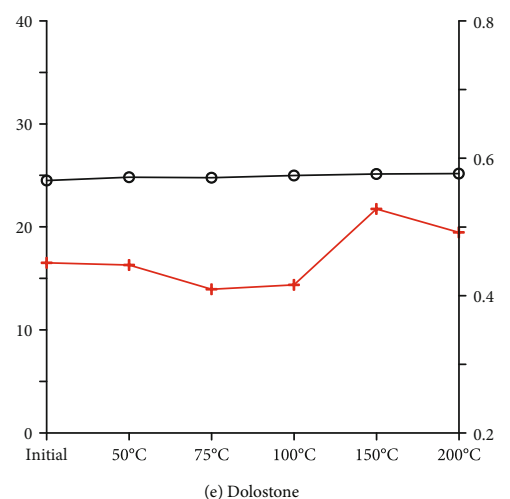

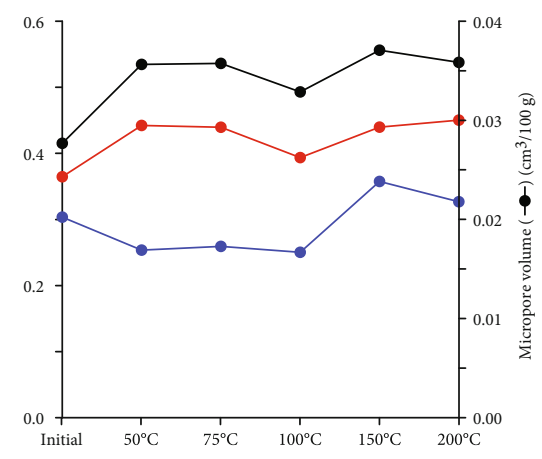

(c) Sandstone

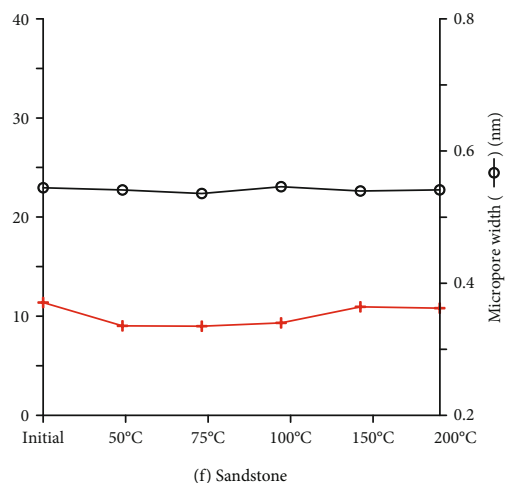

FiguRE 8: Evolution of pore volume ((a) limestone series, (b) dolostone series, and (c) sandstone series) and pore width ((d) limestone series, (e) dolostone series, and (f) sandstone series) of initial and altered rock grains from the simulation. "Initial" describes initial rock grains. Blue, red, and black-filled circles show the volumes of macropores, mesopores, and micropores, respectively. Red crosses show the average widths of macropores and mesopores. Hollow circles show the median widths of micropores. Note that numerical scales differ among the $y$-axes in (a)-(c).

the simulation, the average pore width fluctuated between 19.85 and $30.88 \mathrm{~nm}$ but did not show a clear relationship with simulation temperature (Figure $8(\mathrm{~d})$ ).

The $\mathrm{N}_{2}$ adsorption-desorption isotherms of the initial dolostone samples are similar to that of the initial limestone samples; however, the initial dolostones exhibit a lower adsorption capacity (volume adsorbed $<0.7 \mathrm{~cm}^{3} / 100 \mathrm{~g}$; Figure $7(\mathrm{~b})$ ). In the simulation, the $\mathrm{N}_{2}$ adsorption isotherm and pore-volume distribution variance was more complex. The volume of both mesopores and macropores exhibited a general decreasing trend, although a slight volume increase of macropores occurred at $50^{\circ} \mathrm{C}$ (Figures $7(\mathrm{e})$ and $8(\mathrm{~b})$ ). The average pore width did not change considerably during the first three stages of the simulation (at $50^{\circ} \mathrm{C}$ to $100^{\circ} \mathrm{C}$ ), but increased notably from approximately 14 to $21 \mathrm{~nm}$ during the final two stages (at $150^{\circ} \mathrm{C}$ and $200^{\circ} \mathrm{C}$; Figure $8(\mathrm{e})$ ).

The $\mathrm{N}_{2}$ adsorption-desorption data for the sandstone series showed Type IV isotherm character with a hysteresis loop when P/Po was larger than 0.5 (Figure $7(\mathrm{c})$ ). The Type IV isotherm has been related to the development of slitshaped pores in the aggregates of plate-like grains [31]. The adsorption capacity samples $\left(5.6 \mathrm{~cm}^{3} / 100 \mathrm{~g}\right)$ and pore volume of the initial sandstone samples were higher than those in the limestone and dolostone simulations (Table 4). The pore structure of the initial sandstone samples showed a bimodal distribution with maximum peaks at 2 and $80 \mathrm{~nm}$ (Figure $7(\mathrm{f})$ ). In the simulation, the volume of macropores and mesopores with pore widths greater than $10 \mathrm{~nm}$ decreased in the low-temperature simulation stages $\left(50^{\circ} \mathrm{C}\right.$ to $100^{\circ} \mathrm{C}$ ), then increased during the high-temperature stages $\left(150^{\circ} \mathrm{C}-200^{\circ} \mathrm{C}\right.$; Figure $\left.8(\mathrm{c})\right)$. In contrast, the volume of mesopores with pore widths less than $10 \mathrm{~nm}$ exhibited a reversed trend within the simulation. Overall, the average pore widths varied only to a small degree during the simulation (8.99$11.38 \mathrm{~nm}$; Table 4; Figure 8(f)).

The $\mathrm{CO}_{2}$ adsorption isotherms of initial limestone samples are of Type I (Figure 9(a)), which has been related to microporous solids [31]. All the altered limestones showed similar adsorption capacities, notably lower than those of the initial limestones. The micropore structures of initial and altered samples varied between dimodal and trimodal distributions (Figure 9(d)). Compared with the initial limestones, the volume of micropores with pore widths less than $0.6 \mathrm{~nm}$ decreased dramatically in the simulation (Figures 8 (a) and $9(\mathrm{~d})$ ); however, the median pore width did not change (0.55-0.57 nm; Figure 8(d)).

The $\mathrm{CO}_{2}$ adsorption isotherms of initial dolostone samples are Type I (Figure 9(b)). The adsorption capacity of dolostone increased at $50^{\circ} \mathrm{C}$, then decreased gradually in the subsequent stages of the simulation. Nevertheless, the adsorption capacity of altered dolostone at $200^{\circ} \mathrm{C}$ was still higher than that of the initial samples. The micropore volume distribution followed the evolution of adsorption capacity (Figure 8(b)); however, micropores with different sizes 
TABLE 4: Pore characteristics of initial and altered rock samples.

\begin{tabular}{|c|c|c|c|c|c|c|}
\hline \multirow[b]{2}{*}{ Simulation } & \multirow[b]{2}{*}{$\begin{array}{c}\text { Temperature } \\
\left({ }^{\circ} \mathrm{C}\right)\end{array}$} & \multicolumn{2}{|c|}{$\mathrm{CO}_{2}$ adsorption } & \multicolumn{3}{|c|}{$\mathrm{N}_{2}$ adsorption } \\
\hline & & $\begin{array}{l}\text { Micropore } \\
\left(\mathrm{cm}^{3} / 100 \mathrm{~g}\right)\end{array}$ & $\begin{array}{l}\text { Median pore width } \\
(\mathrm{nm})\end{array}$ & $\begin{array}{l}\text { Mesopore } \\
\left(\mathrm{cm}^{3} / 100 \mathrm{~g}\right)\end{array}$ & $\begin{array}{l}\text { Macropore } \\
\left(\mathrm{cm}^{3} / 100 \mathrm{~g}\right)\end{array}$ & $\begin{array}{c}\text { Average pore width } \\
\text { (nm) }\end{array}$ \\
\hline \multirow{6}{*}{$\begin{array}{l}\text { Limestone } \\
\text { series }\end{array}$} & Initial $^{\mathrm{a}}$ & 0.004 & 0.55 & 0.104 & 0.202 & 26.55 \\
\hline & 50 & 0.002 & 0.57 & 0.077 & 0.095 & 23.50 \\
\hline & 75 & 0.001 & 0.57 & 0.076 & 0.078 & 19.85 \\
\hline & 100 & 0.002 & 0.56 & 0.053 & 0.089 & 31.07 \\
\hline & 150 & 0.002 & 0.57 & 0.070 & 0.113 & 25.19 \\
\hline & 200 & 0.002 & 0.57 & 0.054 & 0.099 & 30.88 \\
\hline \multirow{6}{*}{$\begin{array}{l}\text { Dolostone } \\
\text { series }\end{array}$} & Initial & 0.002 & 0.57 & 0.039 & 0.034 & 16.52 \\
\hline & 50 & 0.010 & 0.57 & 0.031 & 0.038 & 16.30 \\
\hline & 75 & 0.008 & 0.57 & 0.036 & 0.033 & 13.95 \\
\hline & 100 & 0.006 & 0.57 & 0.026 & 0.021 & 14.38 \\
\hline & 150 & 0.004 & 0.58 & 0.023 & 0.025 & 21.75 \\
\hline & 200 & 0.003 & 0.58 & 0.024 & 0.026 & 19.47 \\
\hline \multirow{6}{*}{$\begin{array}{l}\text { Sandstone } \\
\text { series }\end{array}$} & Initial & 0.028 & 0.54 & 0.365 & 0.304 & 11.38 \\
\hline & 50 & 0.036 & 0.54 & 0.442 & 0.254 & 9.03 \\
\hline & 75 & 0.036 & 0.54 & 0.440 & 0.259 & 8.99 \\
\hline & 100 & 0.033 & 0.55 & 0.394 & 0.250 & 9.33 \\
\hline & 150 & 0.037 & 0.54 & 0.440 & 0.358 & 10.95 \\
\hline & 200 & 0.036 & 0.54 & 0.450 & 0.327 & 10.81 \\
\hline
\end{tabular}

${ }^{\mathrm{a}}$ Initial sample.

exhibited different responses. The volume of micropores within $0.7-0.8 \mathrm{~nm}$ increased considerably at $50^{\circ} \mathrm{C}$ and did not vary in the following stages, whereas micropores with pore widths less than $0.7 \mathrm{~nm}$ were enlarged at low temperatures $\left(50^{\circ} \mathrm{C}\right.$ and $\left.75^{\circ} \mathrm{C}\right)$, but diminished gradually in subsequent stages (Figure 9(e)). Overall, the median pore width $(0.57-0.58 \mathrm{~nm}$; Figure $8(\mathrm{e}))$ did not change during the simulation.

The initial sandstone samples showed a relatively lower $\mathrm{CO}_{2}$ adsorption capacity than altered sandstones (Figure 9(c)). Only slight differences in adsorption capacity were observed between altered samples; however, the micropore distribution of the initial and altered sandstones showed dimodal peaks at 0.5 and $0.8 \mathrm{~nm}$, respectively. The simulations increased the volume of micropores but did not change the pore size distribution (Figure 9(f); Figure 8(c)). As such, the median micropore width changed only slightly (0.54$0.55 \mathrm{~nm}$; Figure 8(f)).

\section{Discussion}

4.1. Alteration of Reservoir Rocks by Organic Acid Dissolution. Based on the results shown above, it is clear that reservoir rocks respond differently during organic acid dissolution. Acid dissolution caused rounding of the limestone grains in all orientations (Figures 10). This phenomenon has been observed previously and is explained as a result of the homogeneous dissolution of all lattice planes [32]. It occurs from active sites on lattice defects, convex, and edges, to all sites on crystal surfaces. The homogeneous dissolution continues, thus, more voids develop as holes and cavities. In contrast, micro- and nanometer-sized pores are blocked considerably (Figures 4 and 8(a)). Some pores observed on the surfaces of initial limestone samples were destroyed when the calcite framework surrounding the pores was dissolved. Other pores were likely blocked by migrating fine mineral grains (e.g., silica and dolomite), which were more resistant to dissolution than calcite. These resistant fine mineral grains would have been liberated during dissolution to accumulate in pore throats. In previous simulations, silica grains and clay sheets were exposed on the surfaces of limestone cores dissolved by acid $[22,33]$.

As observed in the limestones, organic acids also dissolved the dolostone samples to a large degree, but the corroded grains developed a honeycomb texture (Figure 10). From SEM observations, it is clear that dissolution began on active sites on rhombohedral cleavages, then corroded these pits along with the cleavage planes deep into the next crystal planes to form a honeycomb texture (Figure 5). This effect has been observed in previous dissolution simulations with dolostone, using different acids [34]. The volume of large pores increased as a result of this pattern of dissolution, but pores $<1 \mu \mathrm{m}$ only showed a small variation in volume (Figure 8(b)). The development of some nanopores could be related to (1) calcite dissolution and (2) corrosion of pits on dolomite grains. Other nanopores are likely blocked by migrating mineral grains, as is the case with the altered limestones. As honeycomb structures develop in actual reservoirs, larger voids in the form of holes and cavities could be expected.

The initial sandstone samples contained only minor carbonate minerals. The calcites, which were mainly cements 


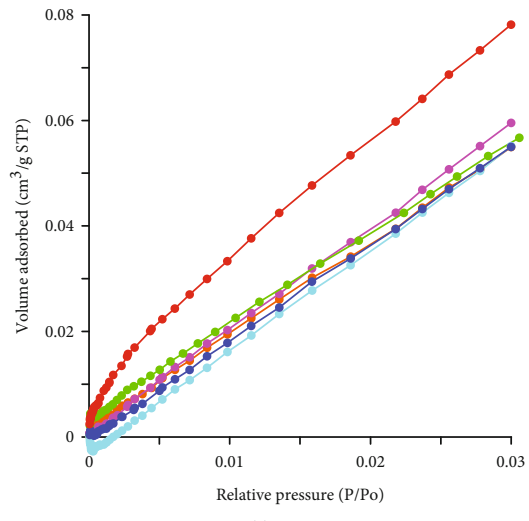

(a) Limestone

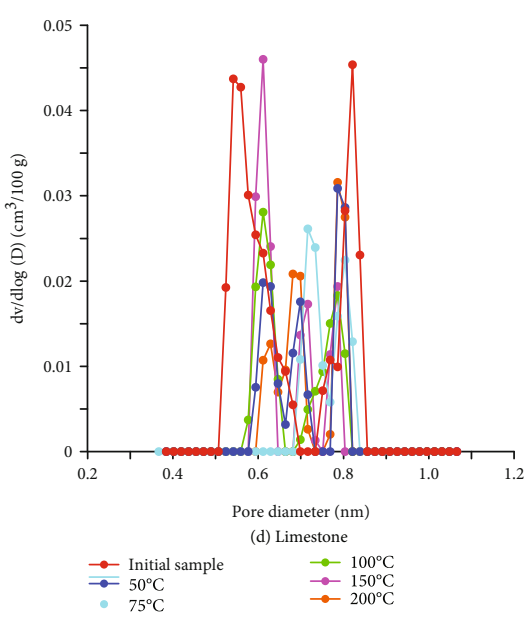

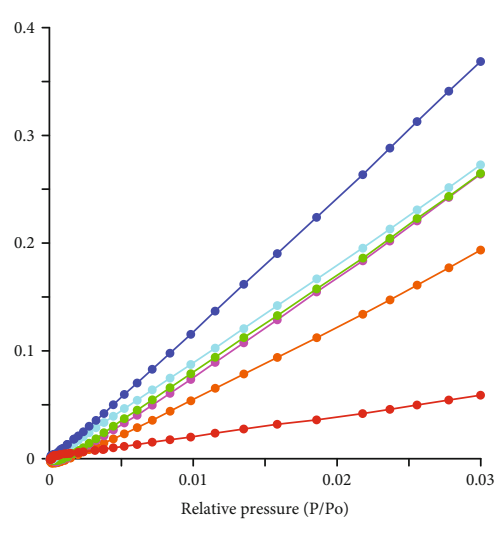

(b) Dolostone

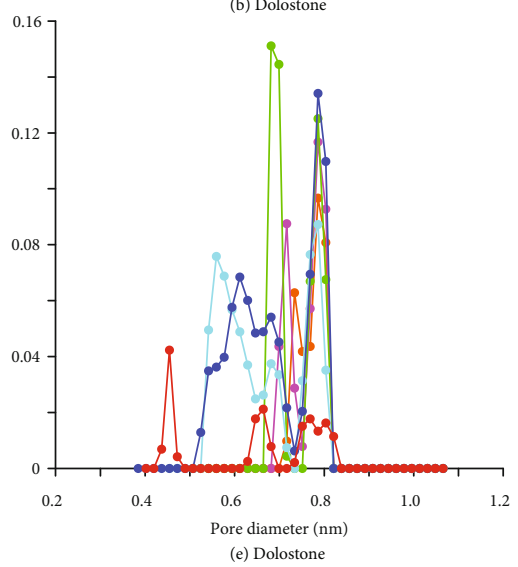

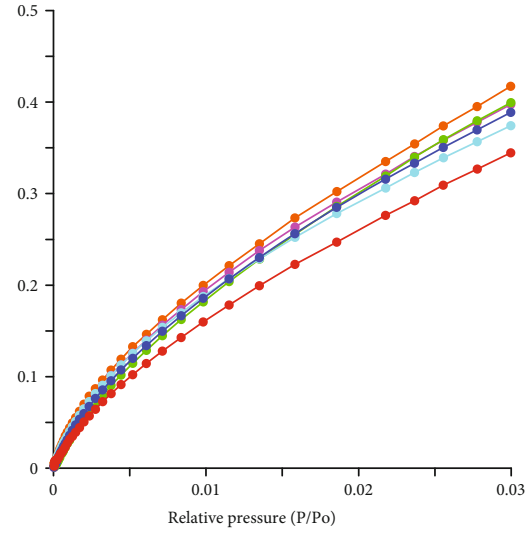

(c) Sandstone

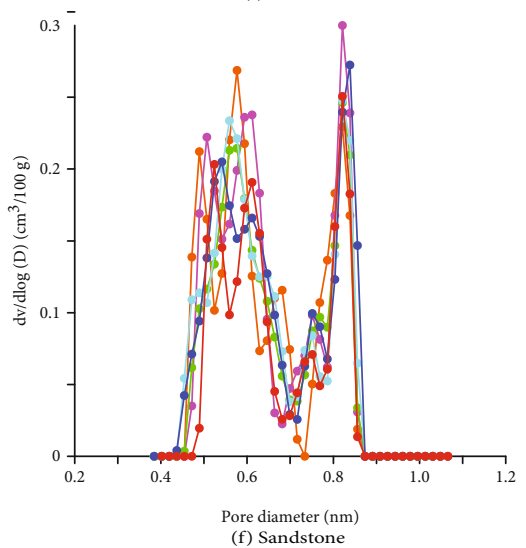

FIGURE 9: $\mathrm{CO}_{2}$ adsorption isotherms for initial and altered rock grains ((a) limestone series, (b) dolostone series, and (c) sandstone series) and pore volume distribution with pore size derived from $\mathrm{CO}_{2}$ adsorption isotherms using the DFT model ((d) limestone series, (e) dolostone series, and (f) sandstone series). Note that numerical scales differ among the $y$-axes.

[16], were dissolved completely during the simulations. The feldspars, quartz, and clay minerals were unaffected (Figure 6). Organic acids dissolve aluminosilicate and quartz through a complex form of $\mathrm{Al}$ and $\mathrm{Si}$ in lattices, but under a markedly slower rate than that of calcite [19-21]. Different dissolution rates were also observed in the water chemistry data from this study. In the simulations, enrichment of $\mathrm{Ca}$ from calcite first occurred during the low-temperature stages, followed by gradual increases in $\mathrm{Si}, \mathrm{K}$, and $\mathrm{Na}$ concentrations as they were released from silicates during higher temperature stages (Table 2). As such, the dissolution of sandstone is heterogeneous, forming microfissures and increasing the connections between different pores after the dissolution of calcite cements (Figures 8(c) and 10). These microfissures are likely to only occur in the micropore size range, as nanopores did not develop during the simulation.

A high acid/rock ratio was used in this simulation in order to speed up the reaction process within a limited time. In geologic settings, dissolution would occur by the same reaction processes, but much more slowly. Despite the temporal difference, the distinct response of different reservoir rocks to acid dissolution in geologic settings should be similar to the simulation results.

4.2. Organic Acid Alteration of Deep Reservoirs. It is generally thought that the oxygen-containing groups in kerogen can be cleaved during source rock maturation, and, thus, they provide a major source of organic acids [34-36]. However, recent laboratory simulation results suggest that thermochemical sulfate reduction and hydrolytic disproportionation, which utilize sulfate and water as electron acceptors, respectively, may generate a certain amount of organic acids in a high-temperature environment [37-39]. This may explain the ongoing reservoir alteration caused by organic acids in deep reservoirs.

Organic acids generated in situ could affect the quality of deep reservoirs in two ways. One is the continuous alteration of reservoirs by mineral dissolution, and the other is the inhibition of mineral precipitation by maintaining acidic conditions. In carbonate reservoirs, porosity may increase via the enlargement of cavities, although the alteration process of these cavities may be different in limestone and dolostone, as described in Section 4.1. In sandstone reservoirs, there is limited potential for increasing porosity in the same manner, as silicate dissolves slowly and the calcite content of the sandstone is minor. However, the permeability of sandstone reservoirs could be improved somewhat after the dissolution of calcite cements. Under normal fluid pressures, microfissures provide little space for hydrocarbon storage; however, overpressure caused by tectonic compression could force these microfissures open, connect them with each other, 

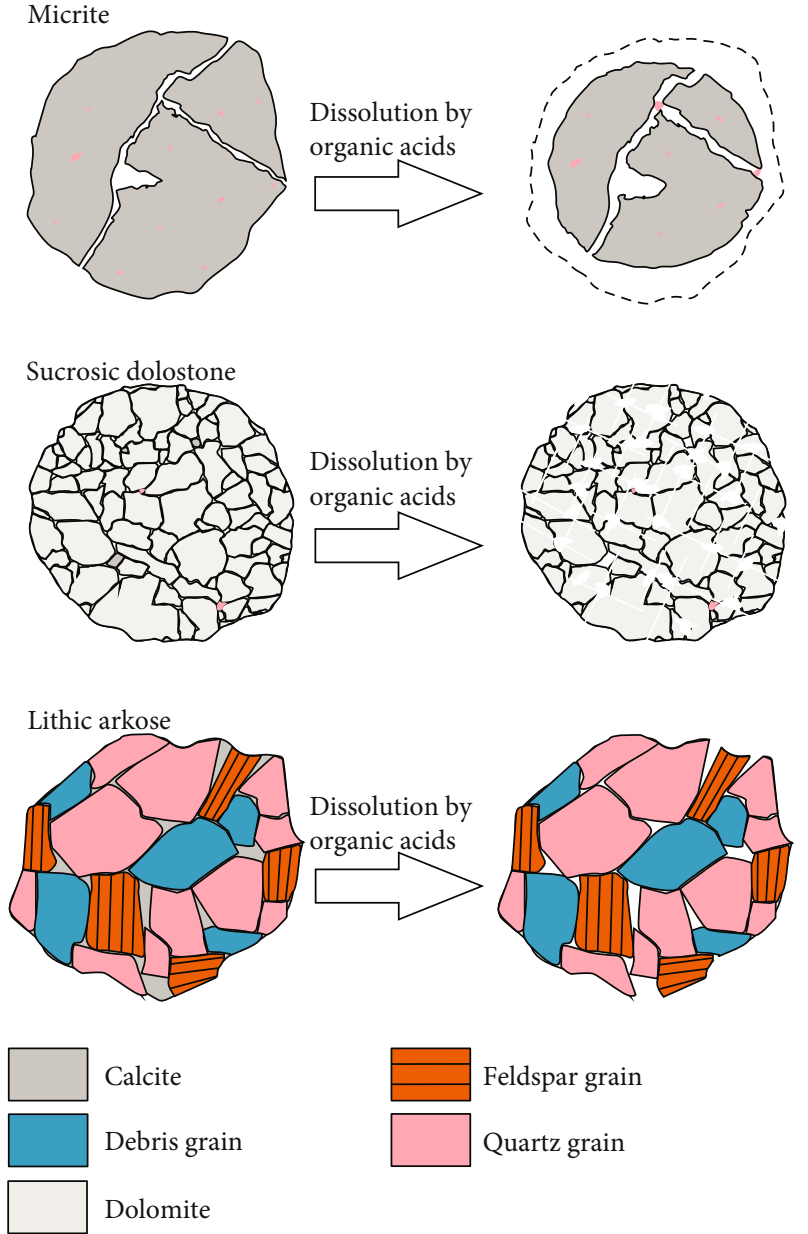

FIGURE 10: Conceptual graph of the dissolution effect of organic acids on selected reservoir rocks. All rock compositions and minerals of the studied samples were drawn according to rock compositions and textures reported in previous studies [24, 26, 27].

and potentially allow hydrocarbon accumulation. The Cretaceous sandstone reservoirs in the Kuqa depression, Tarim Basin, which have developed microfissure porosity in an environment with a pressure coefficient of about 2.0, may represent an example of such acid alteration $[40,41]$.

As noted above, organic acids generated in situ could maintain water acidity and thus inhibit the precipitation of dissolved minerals. The concentrations of acetic acids in the formation water of limestone reservoirs at depths $>5 \mathrm{~km}$ in the Tarim Basin vary from 10.5 to $185.7 \mathrm{mg} / \mathrm{L}$ (median value $=36.8 \mathrm{mg} / \mathrm{L}, n=36$ ) [42]. If all acids were assumed to be acetic acid, a simple calculation on $\mathrm{pH}$ value using the dissociation constants of acetic acids at reservoir temperatures $\left(100^{\circ} \mathrm{C}\right.$ to $\left.150^{\circ} \mathrm{C}\right)$ may be made as follows.

The dissociation process of acetic acids is

$$
\begin{gathered}
\mathrm{CH} 3 \mathrm{COOH} \rightleftharpoons \mathrm{CH} 3 \mathrm{COO}^{-}+\mathrm{H}^{+}, \\
\text {Dissociation constant } \mathrm{Ka}=\frac{\mathrm{C}_{\mathrm{H}+} \cdot \mathrm{C}_{\mathrm{CH} 3 \mathrm{COO}-}}{\mathrm{C}_{\mathrm{A}}}=\frac{\left(\mathrm{C}_{\mathrm{H}+}\right)^{2}}{\mathrm{C}_{\mathrm{A}}},
\end{gathered}
$$

where $\mathrm{C}_{\mathrm{H}_{+}}, \mathrm{C}_{\mathrm{CH} 3 \mathrm{COO},}$, and $\mathrm{C}_{\mathrm{A}}$ are the concentration of $\mathrm{H}^{+}$, $\mathrm{CH}_{3} \mathrm{COO}^{-}$, and acetic acid in the water;

$$
\begin{gathered}
\mathrm{pKa}=-\log _{10} \mathrm{Ka}, \\
\mathrm{pH}=-\log _{10}\left(\mathrm{C}_{\mathrm{H}+}\right),
\end{gathered}
$$

As such, the $\mathrm{pH}$ value is calculated from the following equation:

$$
\begin{aligned}
\mathrm{pH} & =-\log _{10}\left(\mathrm{Ka} \cdot \mathrm{C}_{\mathrm{A}}\right)^{1 / 2}=-\frac{1}{2} \cdot \log _{10}(\mathrm{Ka})-\frac{1}{2} \cdot \log _{10}\left(\mathrm{C}_{\mathrm{A}}\right) \\
& =\frac{1}{2} \cdot \mathrm{pKa}-\frac{1}{2} \cdot \log _{10}\left(\mathrm{C}_{\mathrm{A}}\right) .
\end{aligned}
$$

As the pKa value of acetic acids at $100^{\circ} \mathrm{C}$ is 4.94 , and at $150^{\circ} \mathrm{C}$ is 5.19 [43], the calculated $\mathrm{pH}$ value at $100^{\circ} \mathrm{C}$ is between 3.72 and 4.35 , and at $150^{\circ} \mathrm{C}$ is between 2.85 and 4.47. Therefore, these pore waters would have $\mathrm{pH}$ values of $3.72-4.47$ in the reservoirs. Under these conditions, dissolved minerals would be difficult to precipitate, thus, preserving reservoir porosity.

It has been shown here that the high temperature in deep reservoirs could increase the generation of organic acids from varied reactions, eventually inducing mineral dissolution and porosity preservation in reservoir rocks. However, other factors should be considered in real world examples. One factor is the composition and texture of rocks. Only three types of reservoir rocks were studied here; they may not be representative of reservoir rocks with different mineral and element compositions. In this simulation, because the rocks were crushed to a grain size of 60 to 120 mesh, the effect of rock texture on acid dissolution was negligible. In geological settings, rock composition and texture would influence pore water flow rates and pathways, thereby controlling waterrock interactions, the saturation state of different solute species, and the stability of different minerals (e.g., [44, 45]). Basinal fluid flow could also be another important factor. For example, a recent charging of hydrocarbons and brines $(<10 \mathrm{Ma})$ is evident in deep carbonate reservoirs in the cratonic Tarim Basin, western China [46, 47]. Therefore, perturbations of fluid movement and fluid chemistry, which influence mineral stability, are important considerations when assessing the effect of organic acids on reservoir minerals.

\section{Conclusion}

(1) In the laboratory simulation with rock grains and $0.1 \mathrm{~mol} / \mathrm{L}$ acetic acid in a closed system at $50-200^{\circ} \mathrm{C}$, organic acids dissolved carbonate reservoir rocks (micrite and sucrosic dolostone) more effectively than clastic reservoir rock (lithic arkose). The former lost a weight proportion of $20-30 \%$, while the latter lost a weight proportion of $13 \%$. The porosity increase in all three reservoir types is mainly attributed to the dissolution of carbonate minerals and the corresponding development of micrometer-scale 
pores. In comparison, nanometer-scale pores were only affected to a small degree

(2) The dissolution modes of different mineral compositions vary, owing to the dissolution of organic acids. The micrite was dissolved homogeneously, whereas the sucrosic dolostone was altered through honeycomb-like dissolution. In contrast, the lithic arkose was altered heterogeneously, as only calcite cement was dissolved

(3) Under high-temperature conditions corresponding to the deep basin environment, in situ-generated organic acids could enlarge the existing cavities in carbonate reservoirs and develop microfissures in sandstone reservoirs

(4) Under the experimental conditions used in this study, organic acids inhibit the precipitation of dissolved minerals and, thus, help to preserve reservoir porosity

\section{Data Availability}

The data used to support the findings of this study are included within the article.

\section{Conflicts of Interest}

The authors declare that they have no conflicts of interest.

\section{Acknowledgments}

This study was supported by the National Science and Technology Major Project of China (Grant No. 2017ZX05008003-022) and the State Key Laboratory of Organic Geochemistry (Grant No. SKLOG2020-1).

\section{References}

[1] W. W. Carothers and Y. K. Kharaka, "Aliphatic acid anions in oil-field waters-implications for origin of natural gas," AAPG Bulletin, vol. 62, no. 12, pp. 2441-2453, 1978.

[2] Y. K. Kharaka, G. Ambats, and J. J. Thordsen, "Distribution and significance of dicarboxylic acid anions in oil field waters," Chemical Geology, vol. 107, no. 3-4, pp. 499-501, 1993.

[3] P. D. Lundegard and Y. K. Kharaka, "Geochemistry of organicacids in subsurface waters - field data, experimental data, and models," in ACS Symposium Series 416: Chemical Modeling of Aqueous Systems II, D. C. Melchior and R. L. Bassett, Eds., pp. 169-189, American Chemical Society, Washington DC, 1990.

[4] I. D. Meshri, "On the reactivity of carbonic and organic acids and generation of secondary porosity," in Roles of Organic Matter in Sedimentary Diagenesis, D. L. Gautier, Ed., pp. 123-128, SEPM Special Publication, USA, 1986.

[5] R. C. Surdam, S. W. Boese, and L. J. Crossey, "The chemistry of secondary porosity," in AAPG Memoir 37: Clastic Diagenesis, D. A. Mcdonald and R. C. Surdam, Eds., pp. 127-149, AAPG, Oklahoma, USA, 1984.

[6] R. C. Surdam and P. Yin, "Organic acids and carbonate stability, the key to predicting positive porosity anomalies," in Organic
Acids in Geological Processes, E. D. Pittman and M. D. Lewan, Eds., pp. 398-448, Springer, Berlin, Heidelberg, 1994.

[7] R. C. Surdam, Z. S. Jiao, and D. B. Macgowan, "Redox reactions involving hydrocarbons and mineral oxidants: a mechanism for significant porosity enhancement in sandstones," AAPG Bulletin, vol. 77, no. 9, pp. 1509-1518, 1993.

[8] P. L. Hansley, "Petrologic and experimental evidence for the etching of garnets by organic acids in the upper Jurassic Morrison formation, northwestern New Mexico," Journal of Sedimentary Petrology, vol. 57, no. 4, pp. 666-681, 1987.

[9] Y. Li, X. Gao, S. Meng et al., "Diagenetic sequences of continuously deposited tight sandstones in various environments: a case study from upper Paleozoic sandstones in the Linxing area, eastern Ordos basin, China," AAPG Bulletin, vol. 103, no. 11, pp. 2757-2783, 2019.

[10] Y. Li, W. K. Xu, P. Wu, and S. Meng, "Dissolution versus cementation and its role in determining tight sandstone quality: a case study from the upper Paleozoic in northeastern Ordos Basin, China," Journal of Natural Gas Science and Engineering, vol. 78, article 103324, 2020.

[11] S. N. Ehrenberg, O. Walderhaug, and K. Bjorlykke, "Carbonate porosity creation by mesogenetic dissolution: reality or illusion?," AAPG Bulletin, vol. 96, no. 2, pp. 217-233, 2012.

[12] T. R. Taylor, M. R. Giles, L. A. Hathon et al., "Sandstone diagenesis and reservoir quality prediction: models, myths, and reality," AAPG Bulletin, vol. 94, no. 8, pp. 1093-1132, 2010.

[13] E. D. Pittman and L. A. Hathon, "Material balance considerations for the generation of secondary porosity by organic acids and carbonic acid derived from kerogen, Denver Basin, Colorado, USA," in Organic Acids in Geological Processes, E. D. Pittman and M. D. Lewan, Eds., pp. 115-137, Springer, Berlin-Heidelberg, 1994.

[14] Z. Li, J. Li, P. Zhang, J. Yu, J. Liu, and L. Yang, "Key structuralfluid evolution and reservoir diagenesis of deep-buried carbonates: an example from the Ordovician Yingshan formation in Tazhong, Tarim Basin (in Chinese with English abstract)," Bulletin of Mineralogy, Petrology and Geochemistry, vol. 35, no. 5, pp. 827-838, 2016.

[15] Y. Ma, T. Guo, X. Zhao, and X. Cai, “The formation mechanism of high-quality dolomite reservoir in the deep of Puguang gas field," Science in China Series D: Earth Sciences, vol. 51, no. S1, pp. 53-64, 2008.

[16] D. L. Han, Z. Li, Y. Han, J. Liu, W. Li, and S. Li, "Sealing feature of burial diagenesis environment and its controls on differentiation in Cretaceous sandstone reservoir in Kelasu structure zone, Kuqa depression (in Chinese with English abstract)," Acta Petrolei Sinica, vol. 25, no. 10, pp. 2351-2362, 2009.

[17] P. C. Bennett, "Quartz dissolution in organic-rich aqueous systems," Geochimica et Cosmochimica Acta, vol. 55, no. 7, pp. 1781-1797, 1991.

[18] R. E. Blake and L. M. Walter, "Effects of organic acids on the dissolution of orthoclase at $80^{\circ} \mathrm{C}$ and $\mathrm{pH}$ 6," Chemical Geology, vol. 132, no. 1-4, pp. 91-102, 1996.

[19] J. Cama and J. Ganor, "The effects of organic acids on the dissolution of silicate minerals: a case study of oxalate catalysis of kaolinite dissolution," Geochimica et Cosmochimica Acta, vol. 70, no. 9, pp. 2191-2209, 2006.

[20] L. Yang, T. Xu, M. Wei, G. Feng, F. Wang, and K. Wang, "Dissolution of arkose in dilute acetic acid solution under conditions relevant to burial diagenesis," Applied Geochemistry, vol. 54, pp. 65-73, 2015. 
[21] Q. Ding, Z. L. He, J. B. Wang, and D. Y. Zhu, "Simulation experiment of carbonate reservoir modification by source rock-derived acidic fluids (in Chinese with English abstract)," Oil \& Gas Geology, vol. 41, no. 1, pp. 223-234, 2020.

[22] M. She, Y. Zhu, A. J. Shen, X. P. Zheng, and X. Y. He, "Simulation experiment for the dissolution of carbonate rocks of the Yingshan formation on the northern slope of Tazhong uplift (in Chinese with English abstract)," Carsologica Sinica, vol. 31, no. 3, pp. 234-239, 2012.

[23] W. Pang, H. X. Shi, and J. M. Zheng, "Characteristics of the Ordovician carbonate reservoir in Lunnan area and their controlling factors (in Chinese with English abstract)," Journal of Xi'an Shiyou University (Natural Science Edition), vol. 23, no. 1, pp. 26-29, 2008.

[24] Y. J. Sun, Lithofacies Paleogeography of Lower Ordovician Yingshan Formation in the Cratonic Area of Tarim Basin (in Chinese), [M.S. thesis]., Southwest Petroleum Univesrsity, 2016.

[25] J. Zhou, G. Yao, G. Yang et al., "Lithofacies palaeogeography and favorable gas exploration zones of Qixia and Maokou Fms in the Sichuan Basin (in Chinese with English abstract)," Natural Gas Industry, vol. 36, no. 4, pp. 8-15, 2016.

[26] F. Lu, X. Tan, Y. Zhong et al., "Origin of the penecontemporaneous sucrosic dolomite in the Permian Qixia formation, northwestern Sichuan Basin, SW China," Petroleum Exploration and Development, vol. 47, no. 6, pp. 1218-1234, 2020.

[27] D. L. Han and Z. Li, Diagenetic Dynamic Analysis in Cretaceous Sandstone Resevoirs of Kuqa Depession (in Chinese), Science Press, Beijing, 2016.

[28] H. J. Guo, W. L. Jia, P. A. Peng, J. Zeng, and R. He, "Evolution of organic matter and nanometer-scale pores in an artificially matured shale undergoing two distinct types of pyrolysis: a study of the Yanchang shale with type II kerogen," Organic Geochemistry, vol. 105, pp. 56-66, 2017.

[29] J. L. S. Bell, D. A. Palmer, H. L. Barnes, and S. E. Drummond, "Thermal decomposition of acetate: III. Catalysis by mineral surfaces," Geochimica et Cosmochimica Acta, vol. 58, no. 19, pp. 4155-4177, 1994.

[30] D. A. Palmer and S. E. Drummond, "Thermal decarboxylation of acetate. Part I. The kinetics and mechanism of reaction in aqueous solution," Geochimica et Cosmochimica Acta, vol. 50, no. 5, pp. 813-823, 1986.

[31] K. S. W. Sing, D. H. Everett, R. A. W. Haul et al., "Reporting physisorption data for gas/solid systems with special reference to the determination of surface area and porosity (Recommendations 1984)," Pure and Applied Chemistry, vol. 57, no. 4, pp. 603-619, 1985.

[32] W. X. Zhu, X. Y. Qu, L. W. Qiu, Y. Chen, F. X. Gong, and S. X. $\mathrm{Wu}$, "Characteristics and erosion mechanism of carbonate in acetic acid and hydrochloride solutions, an example from the Nanpu depression (in Chinese with English abstract)," Bulletin of Mineralogy, Petrology and Geochemistry, vol. 34, no. 3, pp. 619-625, 2015.

[33] K. C. Taylor, H. A. Nasr-El-Din, and S. Mehta, "Anomalous acid reaction rates in carbonate reservoir rocks," SPE Journal, vol. 11, no. 4, pp. 488-496, 2006.

[34] M. D. Lewan and J. B. Fisher, "Organic acids from petroleum source rocks," in Organic Acids in Geological Processes, E. D. Pittman and M. D. Lewan, Eds., pp. 70-114, Springer, Berlin-Heidelberg, 1994.
[35] T. Barth, A. E. Borgund, and A. L. Hopland, "Generation of organic compounds by hydrous pyrolysis of Kimmeridge oil shale-bulk results and activation energy calculations," Organic Geochemistry, vol. 14, no. 1, pp. 69-76, 1989.

[36] J. Chen, J. Xu, Q. Wang, S. Wang, Z. Sun, and P. Peng, "The main generation stage of organic acids during source-rock maturation: implications for reservoir alteration in deep strata," IOP Conference Series: Earth and Environmental Science, vol. 600, article 012002, 2020.

[37] S. Yuan, G. S. Ellis, I. M. Chou, and R. C. Burruss, "Experimental investigation on thermochemical sulfate reduction in the presence of 1-pentanethiol at 200 and $250{ }^{\circ} \mathrm{C}$ : implications for_in situ_TSR processes occurring in some MVT deposits," Ore Geology Reviews, vol. 91, pp. 57-65, 2017.

[38] J. S. Seewald, "Organic-inorganic interactions in petroleumproducing sedimentary basins," Nature, vol. 426, no. 6964, pp. 327-333, 2003.

[39] J. S. Seewald, "Model for the origin of carboxylic acids in Basinal brines," Geochimica et Cosmochimica Acta, vol. 65, no. 21, pp. 3779-3789, 2001.

[40] Q. L. Zeng, W. Z. Lu, R. H. Zhang, J. Zhao, P. Ren, and B. Wang, "LIDAR-based fracture characterization and controlling factors analysis: an outcrop case from Kuqa depression, NW China," Journal of Petroleum Science and Engineering, vol. 161, pp. 445-457, 2018.

[41] H. Zhang, R. Zhang, H. Yang et al., "Characterization and evaluation of ultra-deep fracture-pore tight sandstone reservoirs: a case study of cretaceous Bashijiqike formation in Kelasu tectonic zone in Kuqa foreland basin, Tarim, NW China," Petroleum Exploration and Development, vol. 41, no. 2, pp. 175-184, 2014.

[42] J. Chen, Geochemistry of the Oilfield Waters in Middle-Lower Ordovician Paleokarst Reservoir of Lunnan Area, Tarim Basin, [Ph.D. thesis], Guangzhou Institute of Geochemistry, University of Chinese Academy of Sciences, Guangzhou, 2013.

[43] R. W. Smith, C. J. Popp, and D. I. Norman, "The dissociation of oxy-acids at elevated temperatures," Geochimica et Cosmochimica Acta, vol. 50, no. 1, pp. 137-142, 1986.

[44] G. Yuan, Y. Cao, J. Gluyas et al., "Feldspar dissolution, authigenic clays, and quartz cements in open and closed sandstone geochemical systems during diagenesis: typical examples from two sags in Bohai Bay basin, East China," AAPG Bulletin, vol. 99, no. 11, pp. 2121-2154, 2015.

[45] G. Yuan, Y. Cao, Z. Jia et al., "Selective dissolution of feldspars in the presence of carbonates: the way to generate secondary pores in buried sandstones by organic $\mathrm{CO}_{2}$," Marine and Petroleum Geology, vol. 60, pp. 105-119, 2015.

[46] J. Chen, D. Liu, X. Hou et al., "Origin and evolution of oilfield waters in the Tazhong oilfield, Tarim Basin, China, and their relationship to multiple hydrocarbon charging events," Marine and Petroleum Geology, vol. 98, pp. 554-568, 2018.

[47] J. Chen, D. Liu, P. Peng et al., "Iodine-129 chronological study of brines from an Ordovician paleokarst reservoir in the Lunnan oilfield, Tarim Basin," Applied Geochemistry, vol. 65, pp. 14-21, 2016. 